\title{
Cell Signaling and Stress Responses
}

\section{Gökhan S. Hotamisligil ${ }^{1}$ and Roger J. Davis ${ }^{2}$}

${ }^{1}$ Department of Genetics and Complex Diseases, Broad Institute of Harvard-MIT, Harvard School of Public Health, Boston, Massachusetts 02115

${ }^{2}$ Howard Hughes Medical Institute and Program in Molecular Medicine, University of Massachusetts Medical School, Worcester, Massachusetts 01605

Correspondence: roger.davis@umassmed.edu

\section{SUMMARY}

Stress-signaling pathways are evolutionarily conserved and play an important role in the maintenance of homeostasis. These pathways are also critical for adaptation to new cellular environments. The endoplasmic reticulum (ER) unfolded protein response (UPR) is activated by biosynthetic stress and leads to a compensatory increase in ER function. The JNK and p38 MAPK signaling pathways control adaptive responses to intracellular and extracellular stresses, including environmental changes such as UV light, heat, and hyperosmotic conditions, and exposure to inflammatory cytokines. Metabolic stress caused by a high-fat diet represents an example of a stimulus that coordinately activates both the UPR and JNK/p38 signaling pathways. Chronic activation of these stress-response pathways ultimately causes metabolic changes associated with obesity and altered insulin sensitivity. Stress-signaling pathways, therefore, represent potential targets for therapeutic intervention in the metabolic stress response and other disease processes.

\section{Outline}

1 Introduction

2 The unfolded protein response

3 Stress signaling by MAP kinases

\section{Conclusions}

References

Editors: Lewis Cantley, Tony Hunter, Richard Sever, and Jeremy Thorner

Additional Perspectives on Signal Transduction available at www.cshperspectives.org 


\section{INTRODUCTION}

An important aspect of cellular physiology is the maintenance of homeostasis. Evolutionarily conserved biochemical mechanisms play a key role in this process. Thus, exposure to extra- or intracellular stress disrupts cellular homeostasis and causes the engagement of signaling pathways that serve to rebalance biochemical processes within the cell. One example is the AMP-activated protein kinase signaling pathway, which responds to increased AMP and ADP concentrations within the cell by dampening anabolic pathways and promoting catabolic pathways that replenish the ATP supply (Hardie 2012). A second example is the cellular response to DNA damage that engages the ataxia telangiectasia mutated (ATM) stress-signaling pathway to induce growth arrest mediated by the p53 tumor suppressor protein and promote DNA repair before reentry into the cell cycle (Rhind and Russell 2012). A third example is the regulation of receptor ligand sensitivity to control the amplitude of signal transduction. This type of stress response maintains, for example, the dynamic range of vision following exposure to high- and low-intensity light sources (see Julius and Nathans 2012). Similarly, signaling by the metabolic hormones leptin and insulin is dynamically regulated by stress-signaling pathways to control feeding behavior and biosynthetic processes (Hardie 2012). Such pathways are critical for normal cellular homeostasis and adaptive changes in cell physiology that benefit the organism.

In addition to their contributions to normal physiology, stress-activated signaling pathways play roles in establishing dysfunctional states associated with stress exposure and the development of disease. Here, we focus on two different mammalian stress-activated-signaling pathways to illustrate these concepts: the unfolded protein response (UPR) and stress-activated MAP kinase (MAPK) pathways. The UPR is engaged within the endoplasmic reticulum (ER) during biosynthetic stress and leads to a coordinated inhibition of general protein translation and specific upregulation of ER functional capacity. The pathways involved therefore serve to maintain cellular homeostasis. Stress-activated MAPK pathways, in contrast, are regulated by a diverse array of intra- and extracellular stresses, including environmental physical/chemical changes and exposure to inflammatory cytokines. These stress pathways cause phosphorylation of nuclear and cytoplasmic substrates, leading to a network response and adaptation to the new cellular environment.

The UPR and MAPK pathways can function separately or cooperatively. For example, increased saturated fatty acid levels, caused by a high-fat diet, induce both the UPR and stress-activated MAPK pathways. Together, these pathways cause adaptation to the new diet by regulating insulin signaling, blood glucose concentration, and obesity (Fig. 1).

\section{THE UNFOLDED PROTEIN RESPONSE}

The ER is a multifunctional organelle that comprises reticular and tubular structures spanning the cell and has numerous fundamental functions in all cells. It has two major domains: smooth ER, which is devoid of ribosomes; and rough ER, which is studded by attached ribosomes (Palade and Porter 1954; Lynes and Simmen 2011). The rough ER is responsible for the synthesis and trafficking of secreted and integral membrane proteins (Gething and Sambrook 1992; Ellgaard and Helenius 2003), whereas smooth ER is associated with lipid synthesis and metabolism, and calcium storage. The functional specialization within the ER is more complex and various subregions support distinct pathways involved in homeostasis and survival. For example, rough ER is involved in quality control and protein degradation and harbors oxidoreductases (Gething and Sambrook 1992; Ellgaard and Helenius 2003; Kostova and Wolf 2003; Rutkowski and Kaufman 2004; Meusser et al. 2005) and there are additional ER domains devoted to specialized functions including the mitochondria-associated ER membrane (MAM), the nuclear envelope, peroxisomal components, Russell bodies, and lipid droplets

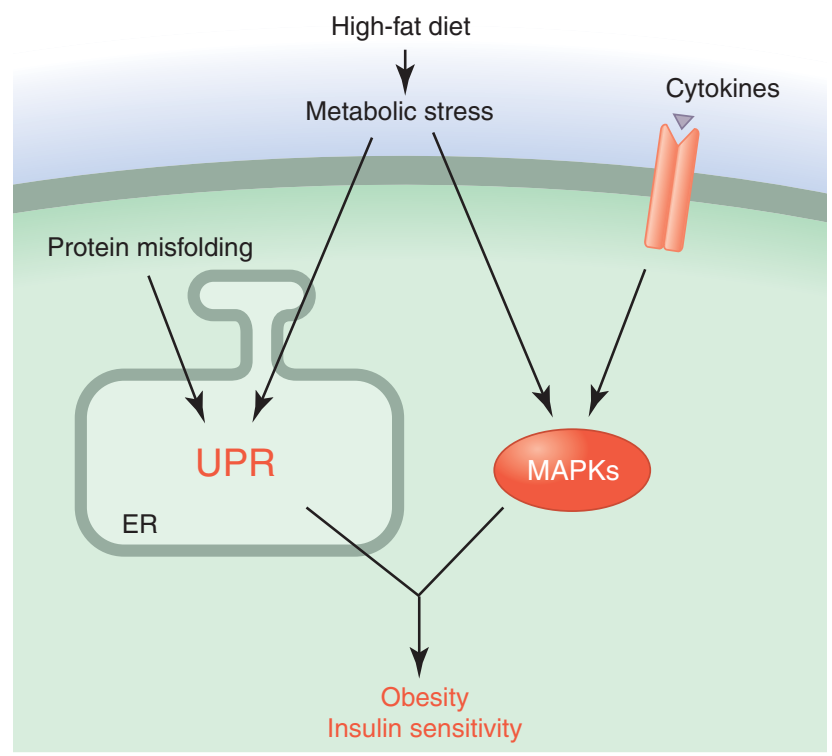

Figure 1. Stress-signaling pathways activated in response to metabolic stress. Feeding mice a high-fat diet causes metabolic stress that leads to the UPR and activation of stress-activated MAP kinases. These signaling pathways result in an adaptive response associated with obesity and altered insulin sensitivity. 
(Lynes and Simmen 2011). Similarly, the smooth ER has specialized domains, such as the plasma membrane-associated ER and regions that can also form MAM, autophagosomes, and lipid droplets (English et al. 2009; Hayashi et al. 2009).

Adaptation of the ER to a variety of metabolic and stress conditions is critical for cell function and survival, as well as organismal health (Walter and Ron 2011). Given the demands fluctuating conditions place on the functional capacity of the ER, a potent adaptive response, the UPR (Mori 2000; Marciniak and Ron 2006; Zhao and Ackerman 2006), has evolved to maintain the functional integrity of this organelle (Fig. 2). In eukaryotic cells, UPR signaling is initiated by three ER-membrane-associated proteins: PERK (PKR-like eukaryotic initiation factor $2 \alpha$ [eIF2 $\alpha$ ] kinase), IRE1 (inositol-requiring enzyme 1), and ATF6 (activating transcription factor 6). Acting in concert, signaling through these branches controls protein synthesis, facilitates protein degradation, and produces the molecules necessary for the ER to restore equilibrium (Mori 2000; Marciniak and Ron 2006; Zhao and Ackerman 2006).

Early studies of adaptive ER responses showed that the levels of two ER-localized chaperones, 78- and 94-kDa glucose-regulated proteins (GRP78 and GRP94), are increased on glucose starvation (Shiu et al. 1977) and protein $N$ glycosylation inhibitors and calcium ionophores enhance their expression (Welch et al. 1983; Resendez et al. 1985; Kim et al 1987). Sambrook and colleagues subsequently observed increased levels of ER chaperones on overexpression of mutant influenza virus hemagglutinin and were the first to propose that malfolded proteins in the lumen of the ER are detected and invoke a response (Kozutsumi et al. 1988). Subsequently, genetic screens in yeast identified IRE1 as an ER-localized receptor-like kinase and ribonuclease required for the ER-to-nucleus signaling that activates chaperone expression under ER stress conditions (Nikawa and Yamashita 1992; Cox et al. 1993; Mori et al. 1993). Hacl was shown to be the leucine-zipper transcription factor that functions downstream from IRE1 to induce transcription by binding to a defined DNA sequence, the UPR element (UPRE) (Cox and Walter 1996; Nikawa et al. 1996) in promoters turned on by the UPR in yeast. The equivalent of $\mathrm{Hacl}$ in multicellular organisms is XBP1 (Shen et al. 2001; Calfon et al. 2002).

An additional cis-acting element (ER stress element, ERSE) was later identified in promoter regions of mammalian ER chaperones and led to the description of another ER-resident leucine-zipper transcription factor, ATF6 (Yoshida et al. 1998). Together, ATF6 and XBP1 stimulate the expression of a broad array of genes involved in protein folding, secretion, and degradation to clear mis- folded proteins from the ER (Walter and Ron 2011). Finally, the third molecule activated during the UPR was identified as PERK, one of the four known eIF2 $\alpha$ kinases (Baird and Wek 2012; Donnelly et al. 2013). It is involved in translational attenuation, temporarily halting arrival of new proteins in the ER (Harding et al. 1999). These three branches are now considered as mediators of the canonical UPR (Fig. 2).

In the canonical model, the intraluminal domains of these initiators (i.e., the amino termini of IRE1 and PERK, and the carboxyl terminus of ATF6) are bound by the chaperone Grp78 (also called BiP) in the absence of stress and rendered inactive (Bertolotti et al. 2000; Shen et al. 2002). Accumulation of improperly folded proteins in the ER lumen results in the recruitment of BiP away from these UPR sensors. Stripping off $\mathrm{BiP}$ allows for oligomerization and activation of PERK and IRE1, and translocation of ATF6 to the Golgi cisternae, which lead to a cascade of downstream signaling events (Shamu and Walter 1996; Bertolotti et al. 2000). Recent studies support the view that more complex luminal events underlie mounting of the UPR. For example, IRE1 can form higher-order oligomers on activation in vitro ( $\mathrm{Li}$ et al. 2010) and directly interact with unfolded proteins (Gardner and Walter 2011). Dynamic regulation of IRE1 by BiP may thus adjust the magnitude of activation as opposed to providing an "on-or-off" switch (Pincus et al. 2010). Hence, it is likely that stress responses emanating from the ER are more complex than the canonical UPR model.

Activation of the ATF6 branch of the UPR requires translocation of ATF6 to the Golgi body and processing by the serine protease site- 1 protease and the metalloprotease site-2 protease to release an active transcription factor (Chen et al. 2002). This branch also responds to signals other than BiP sequestration-for example, the redox status of the ER. Active ATF6 moves to the nucleus to stimulate the expression of genes containing the ERSE1, ERSE2, UPRE, and cAMP-response elements (Sassone-Corsi 2012) in their promoters (Yoshida et al. 1998). Genes required for ER-associated degradation and the gene encoding the ER degradation-enhancing $\alpha$-mannosidase-like protein (EDEM) contain UPREs and, when induced, facilitate clearance and degradation of misfolded proteins from the ER lumen (Yoshida et al. 1998; Friedlander et al. 2000; Kokame et al. 2001).

The oldest branch of the UPR is mediated by IRE1, which is conserved from yeast to humans (Patil and Walter 2001; Calfon et al. 2002). IRE1 has two known isoforms, $\alpha$ and $\beta$, the latter being restricted primarily to the intestine (Wang et al. 1998). IRE1 harbors two distinct catalytic activities: a serine/threonine kinase for which the only known substrate is IRE1 itself, and an endoribonuclease 
A

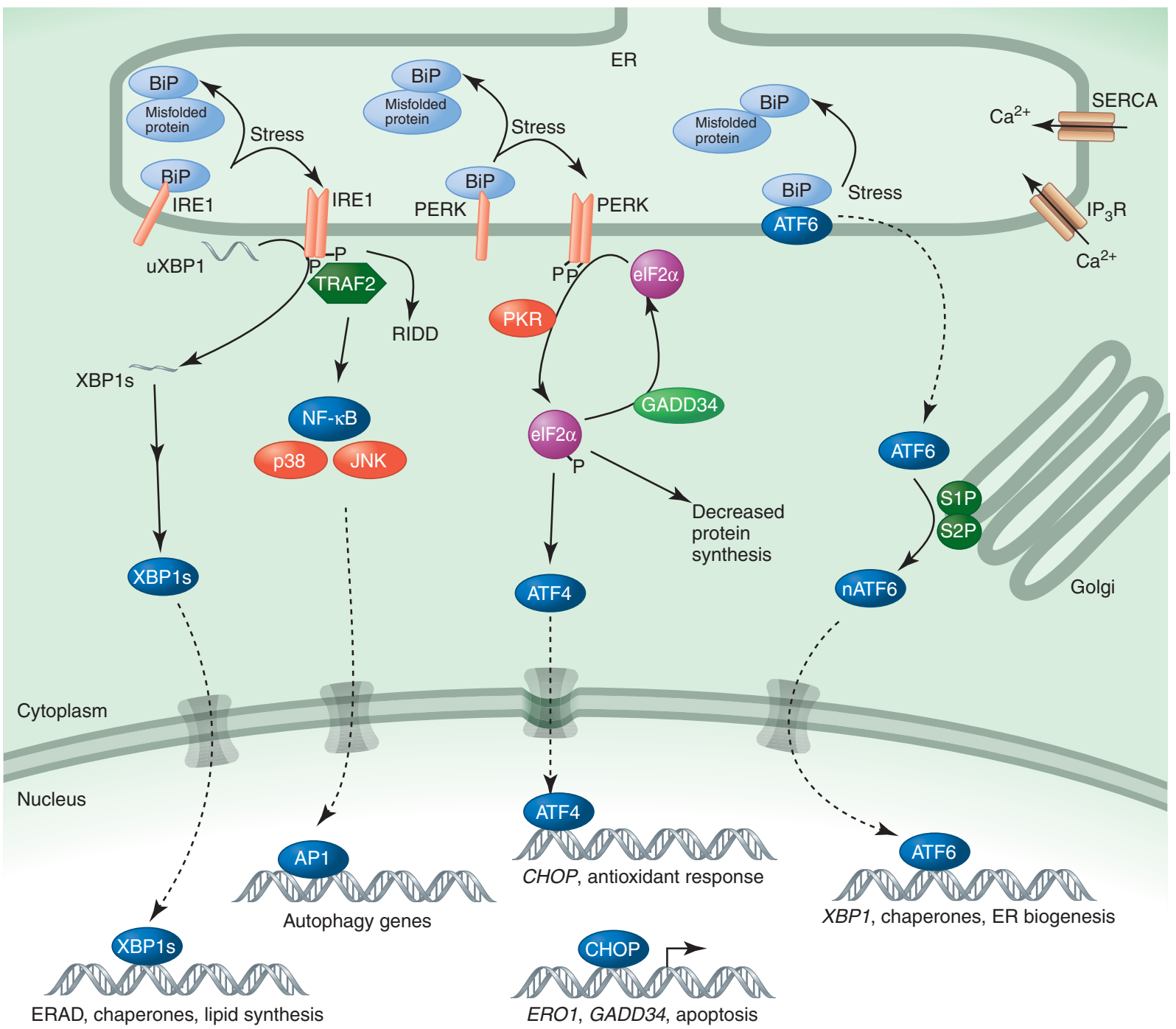

B

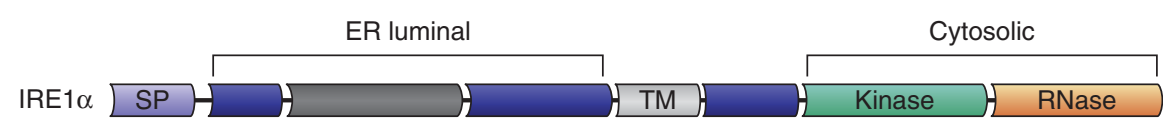

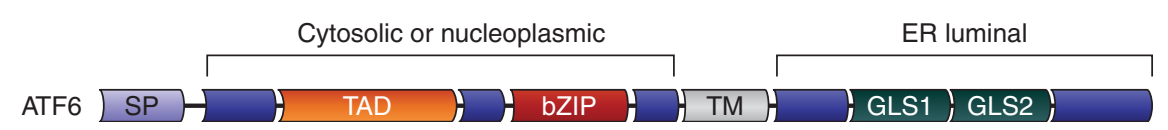

Figure 2. The canonical UPR. (A) In the canonical model of the UPR, unfolded or misfolded proteins activate the three major sensing molecules (IRE1, PERK, and ATF6) at the ER membrane by recruiting the ER chaperone BiP away from the lumenal domains of these proteins. IRE1 is a kinase and ribonuclease that on autophosphorylation activates splicing and produces the active transcription factor XBP1, which induces the expression of ER chaperones, degradation components, and lipid synthesis enzymes. PERK is a kinase that is also activated through dimerization and autophosphorylation and phosphorylates eIF2 $\alpha$ to attenuate general protein synthesis. ATF6 is a transcription factor that once released from the ER will move to the Golgi. After processing at this site, it translocates to the nucleus to activate the transcription of chaperone genes. Together, these pathways reduce entry of proteins into the ER, facilitate disposal of the misfolding proteins, and produce the components for the ER to adapt its folding capacity to reach equilibrium. When these pathways fail to reach homeostasis, they can also trigger death. Under severe stress conditions, the synthesis of ATF 4 is enhanced in an eIF2 $\alpha$-phosphorylation-independent manner that promotes apoptosis. (B) Domain structure of the ER stress sensors IRE1, PERK, and ATF6. SP, signal peptide; TM, transmembrane domain; TAD, transcriptional activation domain; bZIP, basic leucine zipper; GLS1 and GLS2, Golgi localization sequences 1 and 2. Dark gray bars represent regions of limited sequence similarity between IRE1 and PERK. 
activity (Sidrauski and Walter 1997). The endoribonuclease activity is activated on dimerization and autophosphorylation and cleaves a 26-nucleotide intron from the XBP1 messenger RNA (mRNA), generating an mRNA whose translation produces functional XBP1 (so-called XBP1s) (Shamu and Walter 1996; Sidrauski and Walter 1997). $\mathrm{XBP} 1 \mathrm{~s}$, alone or in conjunction with ATF6 $\alpha$, launches a transcriptional program that induces many ER chaperones (including BiP), proteins involved in ER biogenesis, and secretion (for example, EDEM, ERdj4, protein disulfide isomerase [PDI], and other ER proteins) (Yoshida et al. 2001, 2003; Lee et al. 2003). The endonuclease activity of IRE1 can also degrade other mRNAs, preventing their translation and thereby providing an additional way to reduce the translational burden and thus relieve ER stress (Hollien and Weissman 2006). This mechanism has been termed regulated IRE1-dependent degradation.

GTP-bound eIF2 is essential for loading of the initiator Met-tRNA (tRNA) onto an mRNA-charged 40S ribosomal subunit for translation initiation (Hinnebusch and Lorsch 2012). Phosphorylation of its GTP-binding subunit, eIF2 $\alpha$, at S51 by PERK is another important aspect of the UPR. This converts eIF $2 \alpha$ into a competitive inhibitor of eIF2B (the GTP exchange factor for eIF2 $\alpha$ ). This sequesters eIF2B and reduces the rate of regeneration of the eIF2-GTPtRNA $_{i}^{\text {Met }}$ ternary complex, which, in turn, results in lower rates of global protein synthesis, thereby reducing the ER workload (Shi et al. 1998; Harding et al. 1999). At least three other kinases can phosphorylate eIF2 $\alpha$ at S51: double-stranded RNA-dependent kinase (PKR), general control nonderepressible 2, and heme-regulated inhibitor kinase (Baird and Wek 2012; Donnelly et al. 2013). The PERK branch of the UPR is also linked to transcriptional regulation through several distinct mechanisms, which increase the level of and/or activate the transcription factors ATF2, ATF4, C/EBP (Harding et al. 2000; Ma et al. 2002; Ron and Walter 2007), NRF2 (Cullinan et al. 2003), and NF-кB (Jiang et al. 2003; Deng et al. 2004). Generation of the protein products of the induced transcripts is achieved in the context of general translational attenuation through features in the mRNAs that permit their preferential translation. For example, the $5^{\prime}$-end of the ATF4 transcript has two upstream open reading frames (uORFs) that prevent translation under normal circumstances (Somers et al. 2013). However, under stressed conditions, ribosome capacitation is delayed, the uORFs are skipped, and functional ribosome complexes are assembled at the bona fide start codon (Harding et al. 2000). The synthesis of functional ATF4 consequently activates the expression of genes involved in apoptosis, ER redox control, glucose metabolism, and the relief of eIF $2 \alpha$ inhibition (Harding et al. 2000; Ma et al. 2002; Jiang et al. 2004).

\subsection{Noncanonical Aspects of the UPR and Other Stress Signals}

The ER has developed additional strategies to ensure its proper function under stress conditions. For example, the Golgi reassembly stacking protein 1 facilitates the exit of mutant or misfolded proteins from the ER lumen through the activation of an unconventional secretory pathway (Gee et al. 2011). In addition, chaperone-mediated autophagy assists the disposal of misfolded proteins in the ER, and ERphagy (selective autophagy of the ER) promotes the turnover of damaged ER in bulk (Klionsky 2010; Arias and Cuervo 2011). Moreover, during cytokinesis, alternative surveillance mechanisms other than the UPR are also activated to monitor the "fitness" of the ER and ensure its proper transmission into daughter cells (Babour et al. 2010). ER stress also generates oxidative stress that needs to be alleviated during recovery (Cullinan and Diehl 2006). Reactive oxygen species (ROS) are produced in the ER owing to UPR-stimulated up-regulation of protein chaperones involved in disulfide bond formation as well as oxidative phosphorylation in the mitochondria (Sevier et al. 2001). During disulfide bond formation in the ER, electrons are passed through a series of thiol-disulfide exchange reactions from the thiols of the substrate protein to PDI, then to ERO1, and finally to molecular oxygen ( Tu and Weissman 2002). As a byproduct of these reactions, ROS (hydrogen peroxide and other peroxides, superoxide radical, hydroperoxyl radical, and hydroxyl radical) accumulate during the UPR-increased protein folding and can produce sufficiently high levels of ROS to be toxic to the cell (Harding et al. 2003; Sevier and Kaiser 2008). Finally, there are also numerous metabolic adaptations integrated into the UPR (see below).

\subsection{Physiological Roles of the UPR}

In addition to the pathways discussed above, the UPR also engages many other processes that are critical for normal cellular and organismal adaptations (Hotamisligil 2010). Three specific examples are discussed below: (1) survival pathways, apoptosis, and autophagy; (2) immune responses and inflammation; and (3) nutrient sensing and metabolic regulation. In each case, components of the UPR interact with other signaling pathways to control processes beyond simply protein folding and ER stress, which can have effects both within and beyond the cell in which they are activated. A challenging aspect of ER biology is to understand the mechanisms leading to adaptive versus maladaptive/apoptotic responses in the face of stress. It is likely that defective activity or disproportionate (prolonged or imbalanced) engagement of distinct signaling 
networks stimulated by each branch of the UPR is a critical determinant of detrimental outcomes (Hotamisligil 2010).

\subsubsection{Cell Survival and Death Responses of the ER}

Under ER stress conditions, activation of the UPR reduces unfolded protein load through several prosurvival mechanisms, including the expansion of the ER membrane, selective synthesis of key components of the protein folding and quality control machinery, and attenuation of the influx of proteins into the ER. In conditions in which ER homeostasis cannot be established owing to severe or prolonged stress, or unusual challenges (such as those presented by energy or nutrient overload and inflammation), the responses triggered by ER stress result in a maladaptive set of events leading to various cellular or systemic pathologies, including death by apoptosis (Rao et al. 2004; Holcik and Sonenberg 2005; Szegezdi et al. 2006; Scull and Tabas 2011).

When cells are subject to irreparable ER stress, the UPR drives proapoptotic signals to eliminate the damaged material (Green and Llambi 2014). Both PERK and ATF6 induce expression of the transcription factor C/EBP homologous protein (CHOP), which in turn leads to reduced expression of the antiapoptotic gene $B c l 2$ and increased expression of a number of proapoptotic genes (McCullough et al. 2001; Ma et al. 2002; Marciniak et al. 2004). The proteins $\mathrm{p} 58^{\mathrm{IPK}}, \mathrm{GADD} 34$, and TRB3 are also involved in the PERK-mediated apoptotic pathway. These targets have individually been linked to the promotion of apoptosis; GADD34 and $\mathrm{p} 58^{\mathrm{IPK}}$ both negatively regulate eIF2 $\alpha$ signaling and downstream adaptive responses, and TRBP inhibits signaling by the kinase Akt (Novoa et al. 2001; Ladiges et al. 2005; Bromati et al. 2011). IRE1 $\alpha$ activation is linked to apoptosis through its ability to activate the JNK MAPK (Urano et al. 2000) and subsequent downstream phosphorylation of the Bcl2 family members Bim and Bmf, which in turn cause Bax/Bak-dependent apoptosis (Lei and Davis 2003). IRE1 may also regulate the activation of ER-localized caspase-12 through the modulation of a TRAF2-caspase-12 complex (Yoneda et al. 2001; Walter and Ron 2011). Autophagosome formation is accelerated in cells under ER stress (Kroemer et al. 2010), and disturbance of autophagy can render them vulnerable to ER stress and, consequently, lead to death (Ogata et al. 2006). IRE1 $\alpha-J N K$ signaling can trigger autophagy by leading to phosphorylation of $\mathrm{Bcl} 2$, which disrupts $\mathrm{Bcl} 2$-beclin-1 binding. This results in the activation of beclin 1 , an essential autophagy regulator (see Wei et al. 2008; Green and Llambi 2014).

In several different contexts, nutrient-sensing pathways are coupled to ER function, in particular, to the IRE1 axis. This is best illustrated by the coordinated regulation of a major cellular nutrient sensor, the mTORC1 complex (see Laplante and Sabatini 2012), and the UPR. Loss of the mTOR inhibitors TSC1 or TSC2 in cell lines and mouse or human tumors hyperactivates mTORC1 and its downstream network (Yecies and Manning 2011). A key function of mTORC1 is to stimulate overall translational initiation (Proud 2009), which causes ER stress (Ozcan et al. 2008). This can promote mTORC1-mediated negative-feedback inhibition of insulin action and further increase the vulnerability of cells to apoptosis (Ozcan et al. 2008). The UPR is sensitive to the nutritional status of the cell, just like the mTORC1 complex, responding to glucose deprivation, exposure to excess fatty acids, hypoxia, and growth stimuli (Appenzeller-Herzog and Hall 2012). In pancreatic $\beta$ cells, for example, glucose can regulate IRE1 activation by promoting the assembly of an IRE1 $\alpha$-RACK1-PP2A complex. RACK1 is a $\beta$-propeller protein that binds to the $40 \mathrm{~S}$ ribosomal subunit (Coyle et al. 2009; Sharma et al. 2013), linking cell regulation and translation. In response to an acute increase in glucose levels, RACK1 directs PP2A to IRE1 $\alpha$, promoting its dephosphorylation (Qiu et al. 2010). Conversely, ER stress or prolonged exposure to high glucose levels causes RACK1 to dissociate from PP2A, resulting in disruption of this tripartite regulatory module (Qiu et al. 2010). In this scenario, RACK1-associated phosphorylated IRE1 $\alpha$ may have altered functional outputs. The balance in IRE1 signaling is, thus, vital to the survival of these cells and insulin biosynthesis.

\subsubsection{The UPR and Inflammation}

The UPR and other stress-signaling networks are highly integrated with immune signaling (Gregor and Hotamisligil 2011). For example, all three main arms of the UPR regulate NF- $\kappa \mathrm{B}$ signaling during ER stress through distinct mechanisms (Jiang et al. 2003; Kaneko et al. 2003; Deng et al. 2004; Hu et al. 2006; Yamazaki et al. 2009). Moreover, signaling through Toll-like receptors (TLRs) (Lim and Staudt 2013) can activate IRE1, via NOX2-mediated production of ROS, resulting in production of inflammatory cytokines (Martinon et al. 2010). TLRs engage IRE1 $\alpha$, but not the other branches of the UPR, to promote cytosolic splicing and activation of XBP1, which occur in the absence of an ER stress response and do not seem to contribute to the induction of ER-stress-induced genes. Instead, activation of XBP1 by IRE1 promotes sustained production of inflammatory mediators, including interleukin (IL) 6, in certain contexts (Martinon et al. 2010). It is important to emphasize that these responses may not necessarily be related to ER stress per se, despite using IRE1. This distinction and the duration and context of the signaling are critical to determining signaling outcome. 
Links between the immune response and ER stress can be even more complex and involve both innate and adaptive immunity. This is exemplified by the secretory cells of the gut (McGuckin et al. 2011). In intestinal goblets cells, a mutation in mucin 2 (a component of mucus) causes a disease similar to ulcerative colitis in humans with a complex pattern of inflammation involving many immune mediators (Heazlewood et al. 2008). In addition, mutation of mucin 2 results in ER vacuolization and activation of GRP78 and XBP1. Similarly, experimentally triggered ER stress in cultured cells can cause increased expression of many inflammatory molecules, such as IL8, IL6, MCP1, and tumor necrosis factor (TNF) (Li et al. 2005). As mentioned above, ER stress and autophagy are linked, and autophagy is a critical regulator of innate immune responses (Levine et al. 2011). Importantly, cytokines and the pathways they activate influence the function of ER (Zhang et al. 2008; Jiao et al. 2011). Activation of certain pathways, such as those involving JNK and IкB kinase (IKK) (Deng et al. 2004; Hu et al. 2006), and production of certain mediators, such as ROS, all have negative effects on the function of ER (Cullinan and Diehl 2006; Gotoh and Mori 2006; Uehara et al. 2006). The extent of oxidative stress and the levels, duration, and magnitude of ROS and/or NO production can tip the balance in ER responses toward a maladaptive profile (Chan et al. 2011). The metabolic status of the ER (or the metabolic environment within which it has to operate) is thus a key determinant of the balance between adaptive and maladaptive responses.

The kinase PKR, although not known to be physically associated with the ER, is also activated during ER stress (Shimazawa et al. 2007; Nakamura et al. 2010). Once activated, it brings together several key stress and inflammatory signaling molecules, including JNK and insulin-signaling components such as IRS1, with eIF2 $\alpha$. PKR interacts with and directly phosphorylates IRS1 through which it links ER stress to suppression of insulin action. Inflammatory cytokines and toxic lipids, such as palmitate, induce phosphorylation of IRS by PKR, leading to inhibition of insulin signaling. In the absence of PKR activity, neither inflammatory cytokines nor toxic lipids can interfere with insulin action, and deletion of PKR in mice results in significantly improved glucose metabolism.

PKR also contributes to the activation of the NLRP3 inflammasome and HMGB1 (high-mobility group protein B1) production ( $\mathrm{Lu}$ et al. 2012), which are responsible for activation of inflammatory processes (Lamkanfi and Dixit 2012) in response to stimuli such as double-stranded RNA, adjuvant alum and Escherichia coli (Newton and Dixit 2013). PKR also physically interacts with NLRP3, and activates the inflammasome in a cell-free system with recombinant NLRP3, ASC, and procaspase-1 (Lu et al. 2012).
Recent reports also suggest direct regulation of the inflammasome by IRE1 itself via the thioredoxin-interacting protein (TXNIP) (Lerner et al. 2012; Oslowski et al. 2012). Under irremediable ER stress conditions, activation of IRE1 $\alpha$ results in elevated expression of TXNIP, leading to a terminal UPR featuring activation of the inflammasome. Hence, the UPR, through PKR and IRE1, appears to act at the interface of ER stress signaling, inflammatory responses, and metabolic regulation. However, other studies indicate that TXNIP is involved in the endocytosis of the glucose transporter GLUT1 (Wu et al. 2013); so, the connection to inflammasome function may be indirect.

\subsubsection{Metabolic Responses Emanating from the ER}

The ER is critical for regulation of metabolic homeostasis and its dysfunction plays an important role in the emergence of metabolic disease. The ER is sensitive to the metabolic status of cells, responding to feeding-fasting cycles, acute nutrient exposure, and circadian rhythms, and is equipped with direct and indirect means to alter metabolic responses (Cretenet et al. 2010; Hotamisligil 2010; Pfaffenbach et al. 2010; Boden et al. 2011; Hatori et al. 2011). These aspects of ER function are critical in a number of metabolic diseases, such as obesity and type 2 diabetes. Many of the signals generated through the UPR are directly linked to metabolic responses and also engage inflammatory and stress-signaling pathways (Fig. 3), which are also linked to metabolic regulation. Integration of these pathways is critical for glucose metabolism, insulin secretion, insulin action, and the metabolic activities of the ER (Marciniak and Ron 2006; Hotamisligil 2010; Fu et al. 2012).

Insulin is the master regulator of glucose metabolism in mammals and defective insulin action and/or production results in diabetes (Hardie 2012; Ward and Thompson 2012). Obesity and diabetes cause ER dysfunction and/or stress in animal models (Ozcan et al. 2004; Nakatani et al. 2005) and humans (Boden et al. 2008; Sharma et al. 2008; Gregor et al. 2009), and chemicals that reduce ER stress and improve ER function improve glucose metabolism in animal models (Ozawa et al. 2005; Ozcan et al. 2006; Kammoun et al. 2009) and in humans (Kars et al. 2010; Xiao et al. 2011). ER stress responses intersect with insulin action at several points, including the stimulation of JNK by PKR (Nakamura et al. 2010), CaM kinase II ( $\mathrm{Li}$ et al. 2009; Ozcan and Tabas 2012; Ozcan et al. 2012), and IRE1-dependent interaction between TRAF2 and ASK1 (a MAP kinase kinase kinase, MAPKKK) (Urano et al. 2000). This inhibits insulin signaling by uncoupling the insulin receptor from the substrate, IRS1, that mediates its metabolic actions (Hirosumi et al. 2002; Ozcan et al. 2004; Sabio and Davis 2010; Ozcan et al. 2012). 


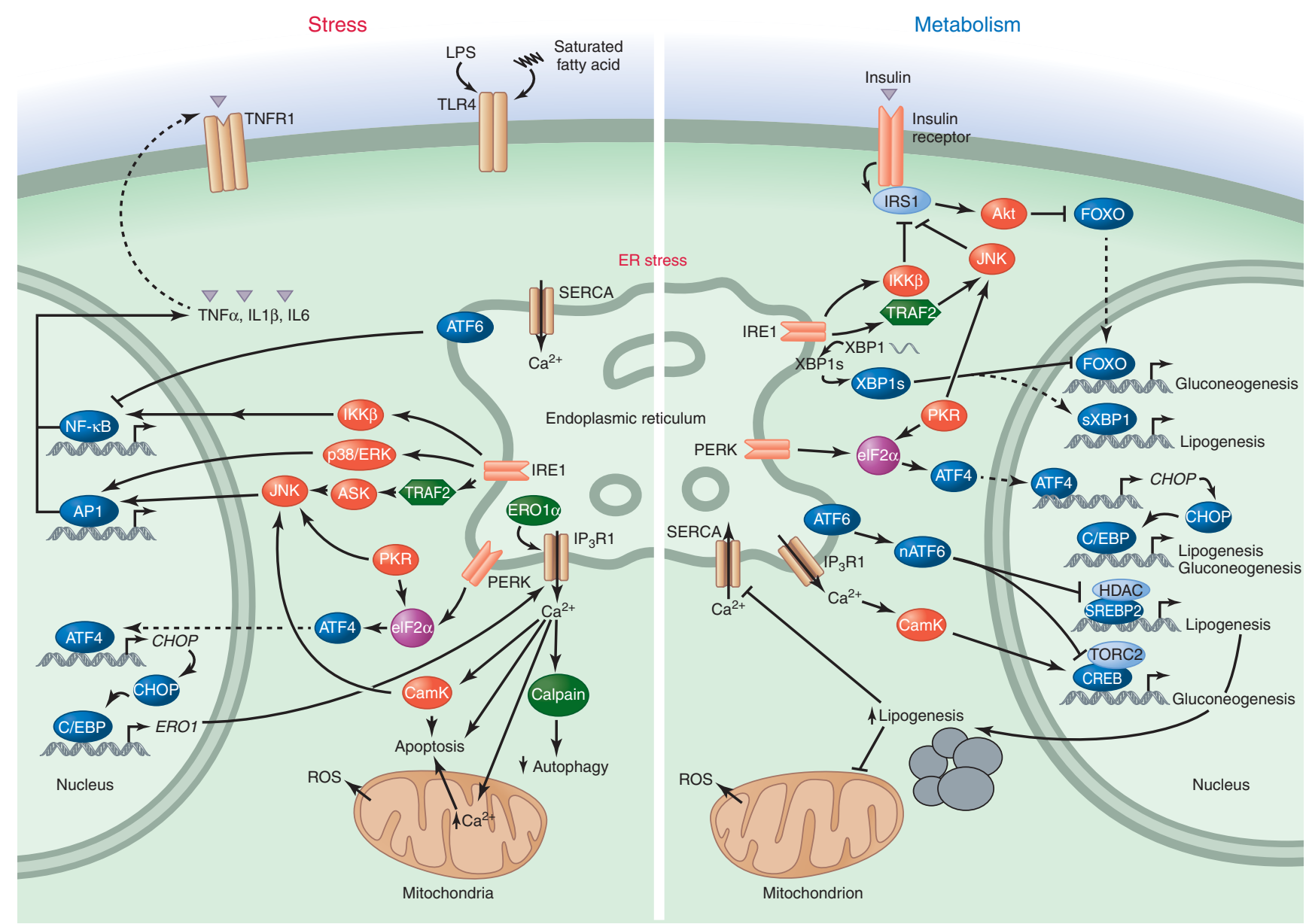

Figure 3. The UPR in stress signaling, inflammation, and metabolism. The UPR contributes to both inflammatory/ stress signaling and metabolic regulation, as exemplified in chronic metabolic diseases. It activates several stressrelated kinases including ERK, p38, JNK, and IKK. The resulting signals can impair signaling by insulin or other endocrine hormones and disrupt metabolism. The UPR can also modulate glucose and lipid metabolism directly. Nuclear ATF6 inhibits gluconeogenesis and lipogenesis by directly binding to TORC2 and SREBP2 proteins, respectively. This mechanism is defective in metabolic disease. The spliced form of XBP1 (XBP1s) can directly or indirectly (through SREBP1) activate the lipogenesis program while inhibiting gluconeogenesis. eIF $2 \alpha$ phosphorylation leads to the synthesis of CHOP and the activation of lipogenesis programs via CEBP $\alpha / \beta$. (Note that the opposing effects of the UPR on gluconeogenesis and lipogenesis are context dependent.) Activation of lipogenesis alters the membrane lipid composition of the ER, inhibits SERCA calcium pumps, and propagates ER stress, which in turn disrupts metabolism further. Hence, inflammatory, stress, and metabolic responses generate a vicious cycle if the ER dysfunction cannot be remedied.

ER stress and inflammation in the central nervous system and gut can also indirectly regulate glucose metabolism in peripheral tissues, particularly the liver (Caricilli et al. 2011; Purkayastha et al. 2011; Milanski et al. 2012). Chronic ER stress affects hypothalamic neuroendocrine pathways that regulate satiety, body weight, and metabolism. Acute ER stress in the brain can induce glucose intolerance and systemic and hepatic insulin resistance, and blocking brain TLR4 or TNF action in obese individuals improves insulin sensitivity and glucose homeostasis in the liver (Mighiu et al. 2012; Milanski et al. 2012). In the gut, alterations in the composition of the gut microbiota seen in TLR2-defi- ciency are accompanied by ER stress, JNK activation, and impaired insulin signaling in the liver (Caricilli et al. 2011). Hence, ER function is part of the inter-organ communication network that ensures metabolic homeostasis.

Insulin is produced by pancreatic $\beta$ cells, which, as professional secretory cells, are heavily dependent on a healthy, functioning ER. Mutations in the PERK branch (WolcottRallison syndrome) of the UPR (Delepine et al. 2000; Harding et al. 2001; Zhang et al. 2002) or the WFS1 gene (for Wolfram syndrome 1), which encodes wolframin, result in death and dysfunction of $\beta$ cells and cause diabetes (Ishihara et al. 2004; Fonseca et al. 2005; Yamada et al. 2006). 
Wolframin targets ATF6 for proteasomal degradation, and its loss results in ER stress signaling mediated by increased levels of ATF6 $\alpha$ (Fonseca et al. 2010). XBP1 deficiency in mice also compromises $\beta$-cell function and survival (Lee et al. 2011a). Moreover, in type 2 diabetes, pancreatic $\beta$ cells also suffer from a vicious cycle of inflammatory alterations, which can compromise the folding capacity of the ER and normal functioning of $\beta$ cells, which progressively lose their ability to produce insulin (Eguchi et al. 2012). This is a challenging problem for therapeutic intervention because both deficiency and hyperactivity of each one of the three UPR branches can be detrimental for $\beta$ cells (Nozaki et al. 2004; Seo et al. 2008; Trusina et al. 2008) and potentially for other cells.

The UPR is thus a critical determinant of metabolic homeostasis. Lipid, carbohydrate, and protein metabolism are all regulated by the UPR, and both the synthesis of and sensitivity to key metabolic hormones, such as insulin, are regulated by these pathways. The survival and function of key cell types critical to metabolism, including pancreatic $\beta$ cells, gut epithelium, and hypothalamic neurons, are controlled by the UPR. Furthermore, the link between inflammation and metabolism is intimately related to ER function.

\section{STRESS SIGNALING BY MAP KINASES}

MAPK pathways are universally conserved eukaryoticsignaling modules that transduce extracellular and intracellular signals to regulatory networks within the cell by phosphorylation of key protein targets (Morrison 2012). MAPKs are activated by dual phosphorylation of tyrosine and threonine residues in a partially unstructured segment (activation loop) between the amino and carboxy-terminal lobes of the catalytic domain (Payne et al. 1991). Phosphorylation on the threonine residue improves the geometry of the active site catalytic residues, leading to formation of hydrogen bonds on the surface of the MAPK that connect the amino-terminal domain to the activation loop and promote closure of the active site cleft. Phosphorylation on the tyrosine residue leads to the creation of new hydrogen bonds and refolding of the activation loop to form a structure that contributes to the substrate-interaction sites (Canagarajah et al. 1997; Rodriguez Limardo et al. 2011). The ERK family of MAPKs are primarily activated by exposure of cells to cytokines and growth factors (Robinson and Cobb 1997). In contrast, the p38 and JNK MAPK families respond primarily to the exposure of cells to extracellular and intracellular stress (Davis 2000; Cuadrado and Nebreda 2010). Consequently, the JNK and p38 MAP kinases are often termed stress-activated MAPKs. They respond to inflammatory cytokines and many changes in the physical/chemical environment, as well as DNA damage and redox imbalance (Fig. 4).

The JNKs are encoded by three genes (JNK1, JNK2, and $J N K 3)$, which are alternatively spliced to yield 10 different isoforms (Gupta et al. 1996). JNK1 and JNK2 are ubiquitously expressed, but JNK3 is expressed primarily in the brain (Davis 2000). Gene disruption studies in mice show that these JNK isoforms can mediate different biological responses (Davis 2000). The p38 MAPKs are encoded by four genes that can be divided into two subgroups ( $p 38 \alpha$ ) $\beta$ and $p 38 \gamma / \delta$ ). These $\mathrm{p} 38$ isoforms show nonredundant functions and different sensitivities to small molecule inhibitors (Cuenda and Rousseau 2007; Cuadrado and Nebreda 2010).

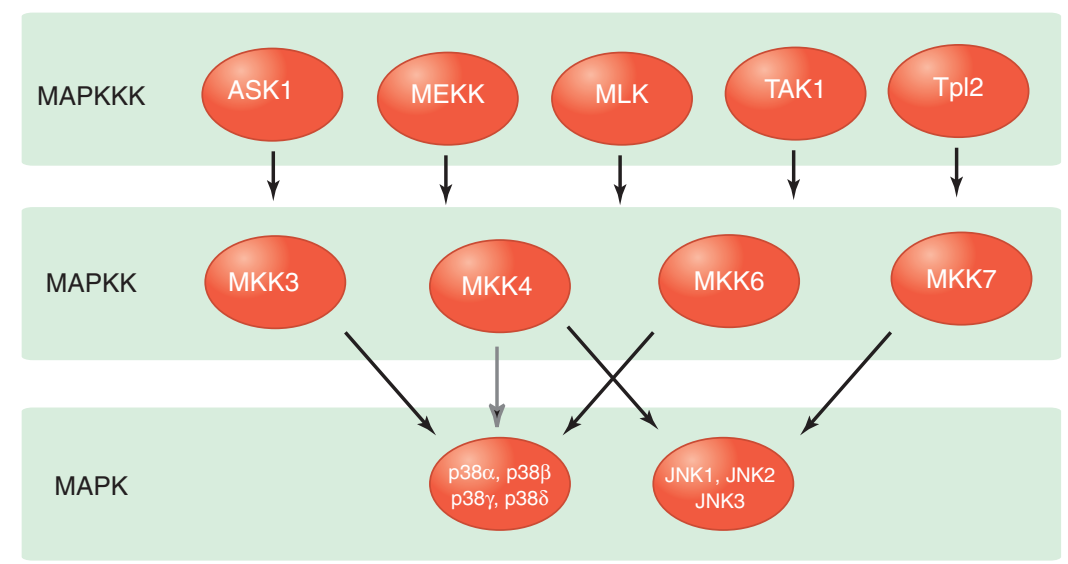

Figure 4. Stress-activated MAPK-signaling pathways. The p38 MAP kinases are primarily activated by the MAPKK isoforms MKK3 and MKK6, but a minor contribution of MKK4 can be detected. All p38 MAPK isoforms are activated by MKK3 and MKK6, although p38 $\delta$ is activated by MKK3 significantly more potently than MKK6. The JNK group of MAPKs is activated by the MAPKK isoforms MKK4 and MKK7. 
The minimal consensus sequence for target protein phosphorylation by MAPKs is -S/T-P-. However, the presence of this consensus motif is not sufficient for phosphorylation by a MAPK, which frequently requires a docking interaction between the MAPK and another region of the substrate (Enslen and Davis 2001; Tanoue and Nishida 2003; Akella et al. 2008). Two types of MAPK docking motifs have been identified in substrates: (1) the FXFP motif, and (2) the D domain, comprising a hydrophobic motif (LXL) plus a basic region (Bardwell and Thorner 1996; Jacobs et al. 1999; Enslen and Davis 2001). Structural analysis of proteins docked to p38 MAPK (Chang et al. 2002) and JNK3 (Heo et al. 2004) show extensive interactions between the docked proteins and regions of the MAPK outside the active site. The sites of D domain and FXFP interaction on MAPKs are different (Akella et al. 2008). In addition to these conserved interactions, the carboxy-terminal sequence of p38 $\gamma$ MAPK can dock directly to proteins that have PDZ domains (e.g., $\alpha 1$ syntrophin, PSD95 [also known as SAP90], and DLG [also known as SAP97]) to direct their phosphorylation (Hasegawa et al. 1999; Hou et al. 2010).

Bioinformatic analyses and protein interaction screens (e.g., two-hybrid assays) have identified many MAPK substrates. More recently, chemical genetic methods and mass spectroscopy have enabled a more comprehensive analysis of MAPK substrates in specific tissues (Allen et al. 2007; Carlson et al. 2011). These include membrane, cytosolic, and nuclear proteins that participate in many biological processes, and especially many transcription factors, such as ATF2 (activated by JNK1/2/3 and p $38 \alpha / \beta$ MAPK), Jun (activated by JNK1/2/3), MEF2C (activated by $\mathrm{p} 38 \alpha / \beta$ MAPK and ERK5), and Elk1 (activated by JNK $1 / 2 / 3$, p38 $\alpha / \beta$ MAPK, and ERK1/2) (Whitmarsh and Davis 2000). Other MAPK targets include protein kinases phosphorylated and activated by MAPKs, including eEF2K (activated by p38 $\gamma / \delta$ MAPK), MK2/3 (activated by $\mathrm{p} 38 \alpha / \beta$ MAPK), MK5 (activated by ERK3/ 4), MNK1/2 and MSK1/2 (activated by ERK1/2 and p38 $\alpha / \beta$ MAPK), and RSK1 $2 / 3$ (activated by ERK1/2) (Cargnello and Roux 2011). Protein phosphatases are also MAPK targets, including nuclear DUSP1 (protected against proteasomal degradation by ERK phosphorylation) and cytoplasmic DUSP6 (proteasomal degradation is promoted by ERK phosphorylation) (Caunt and Keyse 2013). A complete understanding of MAPK function will require a systems-level approach to define the network of interactions that mediate MAPK signaling (Azeloglu and Iyengar 2014). Nevertheless, we already have a good understanding of the roles of these kinases in stress signaling from biochemical and genetic experiments in multiple organisms.

\subsection{MAPK Activation by Stress Signals}

Canonical phosphorylation-dependent activation of a MAPK is mediated by a MAPKK. Different MAPKK isoforms selectively activate particular MAPKs: MKK1 and MKK2 activate ERK1 and ERK2, MKK3 activates p38, MKK4 activates JNK and p38, MKK6 activates p38, and MKK7 activates JNK (Fig. 4). Gene disruption studies in mice have shown that MKK3 and MKK6 are the main MAPKKs responsible for $\mathrm{p} 38$ activation in vivo, although a minor role of MKK4 can be detected (Brancho et al. 2003). This role is supported by biochemical studies that show phosphorylation of $\mathrm{p} 38$ on threonine and tyrosine by both MKK3 and MKK6. Similar gene disruption studies show that MKK4 and MKK7 collaborate in JNK activation (Fleming et al. 2000; Tournier et al. 2001). JNK is preferentially phosphorylated on tyrosine by MKK4 and threonine by MKK7.

Although MAPK activation by MAPKK isoforms represents the major mechanism of MAPK regulation in vivo, noncanonical mechanisms of MAPK activation can be detected under specific circumstances. In yeast, association of the MAPK Fus3 with the scaffold protein Ste5 promotes autophosphorylation of the tyrosine in its activation loop (Bhattacharyya et al. 2006; Good et al. 2009) and autophosphorylation on the activation loop tyrosine of the Smk1 MAPK is driven by its association with the meiosis-specific protein Ssp2 (Whinston et al. 2013). In T cells, the tyrosine kinase Zap70 phosphorylates p $38 \alpha$ on tyrosine and causes subsequent autophosphorylation of the dual phosphorylation motif in the activation loop (Salvador et al. 2005). Similarly, ERK7 is activated by autophosphorylation (Abe et al. 2001). Another noncanonical pathway is represented by the atypical MAPK isoforms ERK3 and ERK4, which can be activated by the protein kinase PAK1 (Deleris et al. 2011).

MAPKKs are themselves activated by phosphorylation of their activation loop by MAPKKKs. Selective activation of MAPKKK isoforms by stress stimuli creates parallel signaling cascades involving sequential phosphorylation of MAPKKs and MAPKs (Fig. 4). These MAPKKKs therefore function to trigger MAPK pathway activation in response to specific stimuli.

The mixed-lineage protein kinase (MLK) group of MAPKKKs are activated by members of the Rho GTPase family, including Rac1 and Cdc42 (Gallo and Johnson 2002). MLK protein kinases are autoinhibited by an interaction between an amino-terminal SH3 domain and a proline motif in the carboxy-terminal region. Binding of GTPbound Rac1 or Cdc42 to MLK protein kinases, mediated by a CRIB motif, causes displacement of SH3-mediated autoinhibition and subsequent protein kinase activation that 
leads to activation of the MAPKK and, subsequently, the MAPK. This mechanism contributes to stress signaling mediated by inflammatory cytokines (Kant et al. 2011). The response to activated Rho proteins may also be mediated by members of the MEKK group of MAPKKKs, including MEKK1 and MEKK4 (Fanger et al. 1997).

The MAPKKK isoform MEKK2 is activated by receptor tyrosine kinases that bind epidermal growth factor, fibroblast growth factor 2 (FGF2), and stem cell factor (SCF, also known as Kit ligand) by a mechanism that has not been defined (Garrington et al. 2000; Kesavan et al. 2004). Activated MEKK2 causes coordinate activation of the ERK5 and JNK pathways (Kesavan et al. 2004).

The stress-induced immediate early gene response can also cause activation of the JNK and p38 MAPK pathways. GADD $45 \alpha, \beta$, and $\gamma$ proteins are expressed in cells exposed to inflammatory cytokines or environmental stress. These are small $(18 \mathrm{kDa})$, acidic, mainly nuclear proteins belonging to the $\mathrm{L} 7 \mathrm{Ae} / \mathrm{L} 30 \mathrm{e} / \mathrm{S} 12 \mathrm{e}$ RNA-binding protein superfamily. They lack obvious enzymatic activity and exert their pleiotropic function by interaction with multiple effectors that influence processes as diverse as cell cycle progression, apoptosis, and DNA repair and demethylation (Niehrs and Schäfer 2012). All GADD45 isoforms can bind to and activate the MAPKKK MEKK4 (Takekawa and Saito 1998). Indeed, mice lacking GADD45 or MEKK4 show similar defects in MAPK signaling (Chi et al. 2004). The binding of GADD45 to MEKK4 disrupts autoinhibition by the MEKK4 amino-terminal domain and causes dimerization, transphosphorylation, and activation of MEKK4 (Miyake et al. 2007).

Redox stress can activate the MAPKKK isoform ASK1 by causing the release of the inhibitor thioredoxin (Matsukawa et al. 2004). Consequently, knockout mice lacking ASK1 expression show severe defects in MAPK signaling during the response to oxidative stress (Matsuzawa et al. 2002).

Stress-activated MAPKs are activated during the DNA damage response by the ATM protein kinase (Rhind and Russell 2012), which phosphorylates and activates members of the TAO group of atypical MAPKKKs (Raman et al. 2007). This mechanism appears to be selective for the $\mathrm{p} 38$ branch of stress-activated MAPK signaling.

Exposure of cells to the inflammatory cytokines TNF and IL1 causes activation of stress-activated MAPKs (Lim and Staudt 2013; Newton and Dixit 2013). This pathway requires the MAPKKK isoform TAK1 and the ubiquitinbinding accessory proteins TAB2 and TAB3. These TAB proteins activate TAK1 when bound to K63-linked polyubiquitin chains formed by the inflammatory receptorsignaling complex (Chen 2012). The TNF receptor causes K63-linked ubiquitylation of RIP1 and TRAF2/ 5 by the E3 ligases cIAP1/2, whereas the IL1 receptor causes K63-linked autoubiquitylation of the E3 ligase TRAF6. A similar ubiquitin-mediated TAK1 activation mechanism is engaged when TLRs bind pathogen-associated molecular patterns to stimulate stress-activated MAPK-signaling pathways (Lim and Staudt 2013; Newton and Dixit 2013). These roles of TAK1 in MAPK activation are coordinated with TAK1-mediated activation of the NF- $\kappa \mathrm{B}$-signaling pathway (Lim and Staudt 2013; Newton and Dixit 2013).

\subsection{Inactivation of Stress-Activated MAPK-Signaling Pathways}

The major mechanism for inactivation of MAPK-signaling pathways is to reverse phosphorylation-mediated activation. Dual-specificity phosphatases (DUSPs, also known as MAPK phosphatases) play a key role in MAPK inactivation (Owens and Keyse 2007; Caunt and Keyse 2013). In addition, MAPKs can be inactivated by the serine/threonine protein phosphatases PP2A and PP2C, tyrosine phosphatases, and the death-effector-domain protein PEA15. The PP2C family member WIP1 plays a major role in switching off the response of p38 to DNA damage (Le Guezennec and Bulavin 2010) and the tyrosine phosphatase HePTP regulates p38 MAPK in B cells following stimulation by adrenalin (McAlees and Sanders 2009). This regulation can display complex dynamics because of phosphorylation-induced regulation of DUSP activity and signal-induced DUSP expression (Keyse 2008). Note that stress-activated MAPK pathways can also be inactivated by bacterial pathogens (Alto and Orth 2012).

\subsection{The Role of Scaffold Proteins}

The protein kinase cascade that is initiated by an activated MAPKKK and includes subsequent MAPKK and MAPK activation represents a defined signaling module. The interactions among the constituent proteins can involve a series of binary docking interactions. For example, as outlined above, a D domain located in the amino-terminal region of a MAPKK can interact with a docking site on MAPKs (Bardwell and Thorner 1996; Enslen and Davis 2001). Cleavage by anthrax lethal factor protease that removes this D domain accounts for the prevention of MAPKK-mediated MAPK activation by this pathogenic bacterium (Duesbery et al. 1998). Similarly, docking interactions between a MAPKKK and MAPKK have been described, including the Phox/Bem1p domain-mediated interactions between MEKK2/3 and MKK5 (Nakamura and Johnson 2007).

MAPK-signaling modules can be assembled by scaffolding proteins (Morrison and Davis 2003; Good et al. 
2011; Witzel et al. 2012). The best-characterized scaffold is Ste5, a component of the yeast-mating response MAPK pathway (Good et al. 2011). Other proteins that regulate mammalian MAPK signaling include scaffolds for the ERK pathway (KSR1), the p38 pathway (OSM, JIP2, and JIP4), and the JNK pathway (JIP1 and JIP3) (Morrison and Davis 2003). Gene disruption studies have confirmed that JIP1 plays a key role in JNK activation caused by the neurotransmitter glutamate (Whitmarsh et al. 2001) and metabolic stress caused by a high-fat diet (Jaeschke et al. 2004; Morel et al. 2010). JIP1 binds to JNK, the MAPKK isoform MKK7, and members of the MLK group of MAPKKKs to form a functional JNK-signaling module. The formation of this signaling complex is regulated by phosphorylation (Morel et al. 2010). Moreover, JIP1 interacts with kinesin light chain and is dynamically localized within the cell by microtubule-mediated protein trafficking. This scaffold protein allows regulatory control of localization, module activation, and substrate access to direct stress-activated MAPK signaling to specific targets within the cell (Morrison and Davis 2003).

\subsection{Physiological Role of Stress-Activated MAPKs}

Like the UPR, stress-activated MAPKs contribute to many aspects of normal cellular physiology and pathology (Davis 2000; Cuadrado and Nebreda 2010). Below, we discuss their roles in the context of three specific examples: cell death versus survival signaling, inflammatory stress, and metabolic stress.

\subsubsection{Stress-Activated MAPKs and Cell Death}

The initial response of cells to stress exposure is to mount a survival response, but prolonged exposure to stress may lead to cell death (Green and Llambi 2014). MAPKs are implicated in these processes (Xia et al. 1995). Studies of TNF-stimulated cell death show that JNK initially promotes a survival response and that prolonged JNK activation is required for cell death (Lamb et al. 2003; Ventura et al. 2006). Sustained activation of JNK and p38 can contribute to both necrotic and apoptotic cell death by regulating the expression of cytotoxic ligands (e.g., FasL and TNF) (Das et al. 2009) and synthesis of ROS (Ventura et al. 2004). In addition, stress-activated MAPKs can regulate the intrinsic apoptosis pathway, mediated by mitochondria, by regulating members of the $\mathrm{Bcl} 2$ family (Tournier et al. 2000). Thus, JNK can phosphorylate and inhibit prosurvival signaling by Mcl1 by inducing ubiquitin-dependent proteasomal degradation (Morel et al. 2009) and JNK can cause induction of the proapoptotic $\mathrm{BH} 3$-only protein Bim (Wong et al. 2005; Perier et al. 2007). Bim is also subject to posttranslational regulation by MAPKs (Puthalakath and Strasser 2002). ERK phosphorylation on multiple serine residues sites triggers ubiquitin-independent proteasomal degradation of Bim (Wiggins et al. 2011). In contrast, JNK phosphorylation of Bim on a threonine residue disrupts the interaction of Bim with the dynein microtubule motor complex that can sequester Bim on the microtubule cytoskeleton (Lei and Davis 2003; Hubner et al. 2008). The Bim-related protein Bmf is similarly regulated by JNK-mediated phosphorylation, which disrupts the interaction of Bmf with the myosin $\mathrm{V}$ motor complex that sequesters Bmf on the actin cytoskeleton (Lei and Davis 2003; Hubner et al. 2010). JNK therefore promotes the intrinsic apoptotic pathway by degrading the antiapoptotic protein Mcll and up-regulating the proapoptotic protein Bim by multiple mechanisms, including increased transcription and sequestration of Bim by the cytoskeleton. The loss of the antiapoptotic protein Mcll combined with the increase in Bim activity causes a change in the balance of pro- and antiapoptotic pathways that leads to cell death. This balance of cell death and survival regulated by stressactivated MAPKs is also influenced by the activation state of survival signaling pathways, including those involving Akt, ERK, and NF- $\kappa$ B.

In vivo studies have shown that stress-activated MAPKs play a critical role in neurodegenerative disorders, including stroke (Kuan et al. 2003), seizure (Yang et al. 1997), Alzheimer's disease (Mazzitelli et al. 2011), and Parkinson's disease (Perier et al. 2007). Cell death regulated by stressactivated MAPKs may also play an important role during tumor development (Davis 2000).

\subsubsection{Stress-Activated MAPKs and Inflammation}

MAPKs contribute to both innate and adaptive immune responses (Dong et al. 2002). In particular, stress-activated MAPKs play an important role in the regulation of inflammatory cytokine expression. The p38 and JNK pathways target transcription factors (e.g., ATF, Jun, and MEF2 family members) and chromatin-remodeling enzymes that can regulate expression of chemokines (e.g., CCL2 and CCL5) and cytokines (e.g., IL1, IL6, IL12p40, and TNF) during inflammatory responses (Davis 2000; Cuadrado and Nebreda 2010). In addition, $\mathrm{p} 38 \alpha$ increases cytokine mRNA stability controlled by the AU-rich element-binding proteins HuR (phosphorylated by p38) and TTP (phosphorylated by p38 $\alpha$-MAPK-activated MK2) (Clark et al. 2009). p38 $\alpha$ can also stimulate cytokine mRNA translation by phosphorylation and activation of eIF4E/MAPK-interacting kinases (MNK1 and MNK2) (Noubade et al. 2011). Moreover, p38 $\gamma$ and $\mathrm{p} 38 \delta$ increase cytokine translation by phosphorylation and activation of eEF2K, which in- 
creases protein synthesis (Gonzalez-Teran et al. 2013). Thus, JNK and p38 coordinately regulate transcription, mRNA stability, and mRNA translation to promote cytokine/chemokine expression.

The immune response elicited during inflammation depends on the involvement of specific innate and adaptive immune cells. These types of cells are influenced by stressactivated MAPK-signaling pathways. Macrophages represent an important part of the innate immune response. Classical activation of macrophages by interferon $\gamma$ or endotoxin causes polarization to the M1 phenotype that is associated with expression of inflammatory cytokines (e.g., $\mathrm{TNF}$ ) and inflammation. In contrast, alternatively activated macrophages polarized to the M2 phenotype can express anti-inflammatory cytokines (e.g., IL10) and are implicated in resolution of the immune response and tissue remodeling. The M2 phenotype is complex and represents a mixture of different cell types, including cells exposed to IL4 or IL13 (M2a), immune complexes (M2b), and IL10 or TGF $\beta$ (M2c). Stress-activated MAPKs can control macrophage polarization. For example, JNK is required for M1, but not M2, macrophage development (Han et al. 2013). Consequently, JNK can promote inflammation by polarizing macrophages to the $\mathrm{M} 1$ inflammatory phenotype. In contrast, JNK inhibition can suppress inflammation by increasing polarization to the M2 anti-inflammatory phenotype.

Stress-activated MAPKs can also regulate the formation of specific T-cell subsets. For example, JNK is required for $\mathrm{CD}^{+}$cell proliferation and IL2 secretion (Conze et al. 2002). In contrast, it is not required for $\mathrm{CD} 4^{+} \mathrm{T}$-cell activation or IL2 secretion, but JNK is required for naïve $\mathrm{CD} 4^{+}$ T-cell differentiation into Th1 or Th2 effector cells (Dong et al. 2000). Moreover, p38 $\alpha$ is required for differentiation of $\mathrm{CD}^{+}{ }^{+}$T cells into Th17 cells (Noubade et al. 2011). A consequence of these roles in T cells is that JNK is required for efficient viral clearance (Arbour et al. 2002) and p38 is required for suppression of autoimmunity (Noubade et al. 2011).

Collectively, these mechanisms lead to inflammation in tissues with increased stress-activated MAPK activity, which can promote metabolic dysfunction (Sabio and Davis 2010) and carcinogenesis (Das et al. 2011).

\subsubsection{Stress-Activated MAPKs and Metabolism}

Feeding a high-fat diet causes metabolic stress and activates stress-activated MAPK-signaling pathways. This is mediated by increased amounts of saturated free fatty acids that activate the MLK group of MAPKKKs (Jaeschke and Davis 2007; Kant et al. 2013). The mechanism of fatty acid signaling may require G-protein-coupled receptors (Talukdar et al. 2011) or nonreceptor mechanisms (Holzer et al. 2011) that activate the tyrosine kinase Src in lipid raft domains of the plasma membrane (Holzer et al. 2011). p38 $\alpha$ and p38 appear to have roles in insulin resistance, oxidative stressinduced $\beta$-cell failure, and hepatic gluconeogenesis ( $\mathrm{Su}-$ mara et al. 2009; Lee et al. 2011b). Moreover, the JNK pathway is required for high-fat-diet-induced obesity and insulin resistance (Hirosumi et al. 2002).

The effects of JNK on obesity are due to a requirement for JNK in negative feedback regulation of energy expenditure by the hypothalamus-pituitary-thyroid axis (Sabio and Davis 2010). The activation of JNK inhibits the expression of hypothalamic thyrotropin-releasing hormone and pituitary gland expression of thyroid-stimulating hormone. The consequence of JNK-mediated suppression of the hypothalamic-pituitary-thyroid axis is that levels of circulating thyroid hormone, thyroid-hormone-dependent target gene expression, and oxidative metabolism are all decreased, which reduces energy expenditure, and obesity is increased.

The effects of JNK on insulin resistance depend on roles of JNK in peripheral tissues that are independent of obesity (Sabio and Davis 2010). Activated JNK causes inhibition of signaling by the insulin receptor. Initial studies indicated that this might be mediated by inhibitory phosphorylation of IRS1 (Aguirre et al. 2000), but this conclusion was not supported by later studies (Copps and White 2012). The mechanism of inhibition of insulin receptor signaling by JNK remains to be elucidated. However, one potential mechanism that may contribute to insulin resistance is the requirement of JNK for macrophage polarization to the M1 phenotype because tissue infiltration by inflammatory macrophages is a key determinant of the development of insulin resistance (Han et al. 2013). It is clear that loss of JNK function in murine models protects mice against the development of insulin resistance when fed a high-fat diet (Sabio and Davis 2010). This observation is important because compensation of insulin resistance by hyperinsulinemia can lead to $\beta$-cell failure and diabetes. Because stress-activated MAPKs play a key role in energy homeostasis and normal glycemia, they represent potential targets for therapies aimed at treatment of metabolic syndrome and prediabetes (Sabio and Davis 2010).

\section{CONCLUSIONS}

Stress-signaling pathways are evolutionarily conserved and play an important role in the maintenance of homeostasis and adaptation to new cellular microenvironments (Fig. 5). Key areas for future research include structural studies of stress-response signaling proteins and integrated analysis of the signaling network's response to stress. 


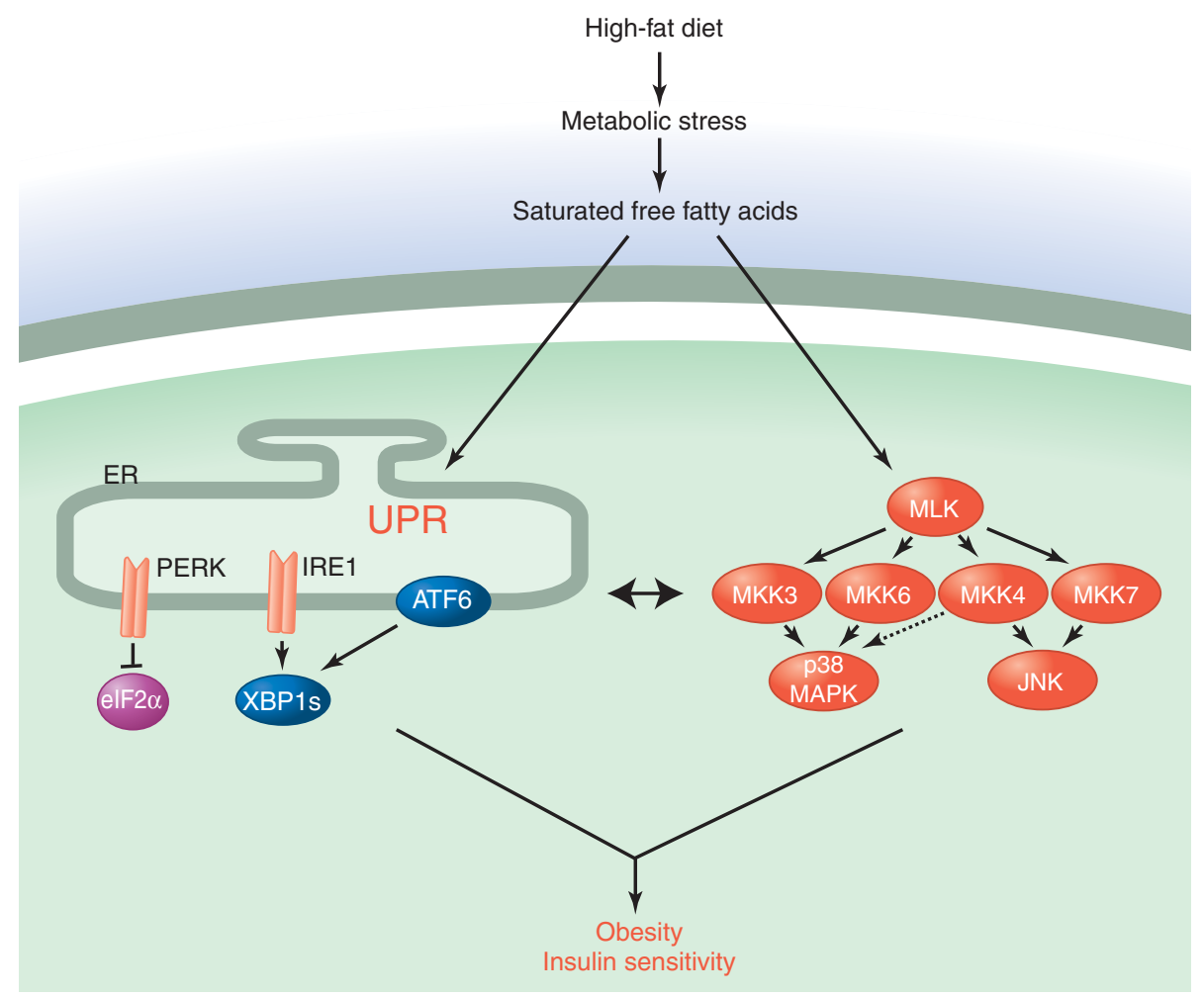

Figure 5. Integrated response to metabolic stress. A high-fat diet causes metabolic stress associated with increased amounts of saturated free fatty acids, which engage the UPR and stress-activated MAPKs. The UPR includes three different signaling pathways that are initiated by IRE1, PERK, and ATF6. The stress-activated MAPK response is initiated by the MLK group of MAPKKKs and leads to the activation of the JNK and p38 MAPKs. Cross talk between the UPR and stress-activated MAPK signaling leads to an integrated adaptive response.

Finally, studies of stress-signaling pathways that translate to the clinic are needed if we are to realize their potential for therapeutic intervention in disease processes. Effective and specific means to target both MAPK signaling and the UPR are required. An important area of research will be the development of molecular tools that allow us to specifically modulate the function of the key components of MAPK pathways. Similarly, we must define new targets within the UPR and develop new tools to modulate its components.

\section{ACKNOWLEDGMENTS}

Studies in the Hotamisligil laboratory are currently supported by grants from the National Institutes of Health (NIH), the Juvenile Diabetes Research Foundation, the American Diabetes Association, Servier and UCB Pharmaceuticals, and the Simmons Fund. Special thanks to Scott Widenmaier, Ling Yang, and Takahisa Nakamura for critical discussions, thoughtful comments, and help in preparing the manuscript, Ana Paula Arruda and Suneng Fu for help in illustrations, and Megan Washack and Claudia Garcia Wagner for editorial assistance. Studies in the Davis laboratory are currently supported by grants from the $\mathrm{NIH}$, the American Diabetes Association, and the Howard Hughes Medical Institute. Kathy Gemme provided expert editorial assistance. We thank the students and fellows who contributed to the studies in our groups over the years and to our collaborators. We regret the inadvertent omission of references to important work by our colleagues because of space limitations.

\section{REFERENCES}

* Reference is also in this collection

Abe MK, Kahle KT, Saelzler MP, Orth K, Dixon JE, Rosner MR. 2001. ERK7 is an autoactivated member of the MAPK family. J Biol Chem 276: $21272-21279$.

Aguirre V, Uchida T, Yenush L, Davis R, White MF. 2000. The c-Jun $\mathrm{NH}_{2}$-terminal kinase promotes insulin resistance during association with insulin receptor substrate-1 and phosphorylation of $\mathrm{Ser}^{307}$. J Biol Chem 275: 9047-9054.

Akella R, Moon TM, Goldsmith EJ. 2008. Unique MAP kinase binding sites. Biochim Biophys Acta 1784: 48-55. 
Allen JJ, Li M, Brinkworth CS, Paulson JL, Wang D, Hübner A, Chou W-H, Davis RJ, Burlingame AL, Messing RO, et al. 2007. A semisynthetic epitope for kinase substrates. Nat Methods 4: 511-516.

* Alto NM, Orth K. 2012. Subversion of cell signaling by pathogens. Cold Spring Harb Perspect Biol 4: a006114.

Appenzeller-Herzog C, Hall MN. 2012. Bidirectional crosstalk between endoplasmic reticulum stress and mTOR signaling. Trends Cell Biol 22: 274-282.

Arbour N, Naniche D, Homann D, Davis RJ, Flavell RA, Oldstone MB. 2002. c-Jun $\mathrm{NH}_{2}$-terminal kinase (JNK) 1 and JNK2 signaling pathways have divergent roles in $\mathrm{CD}^{+} \mathrm{T}$ cell-mediated antiviral immunity. J Exp Med 195: 801-810.

Arias E, Cuervo A. 2011. Chaperone-mediated autophagy in protein quality control. Curr Opin Cell Biol 23: 184-189.

* Azeloglu EU, Iyengar R. 2014. Signaling networks: Information flow, computation, and decision making. Cold Spring Harb Perspect Biol doi: $10.1101 /$ cshperspect.a005934.

Babour A, Bicknell A, Tourtellotte J, Niwa M. 2010. A surveillance pathway monitors the fitness of the endoplasmic reticulum to control its inheritance. Cell 142: 256-269.

Baird TD, Wek RC. 2012. Eukaryotic initiation factor 2 phosphorylation and translational control in metabolism. Adv Nutr 3: 307-321.

Bardwell L, Thorner J. 1996. A conserved motif at the amino termini of MEKs might mediate high-affinity interaction with the cognate MAPKs. Trends Biochem Sci 21: 373-374.

Bertolotti A, Zhang Y, Hendershot LM, Harding HP, Ron D. 2000. Dynamic interaction of BiP and ER stress transducers in the unfoldedprotein response. Nat Cell Biol 2: 326-332.

Bhattacharyya RP, Reményi A, Good MC, Bashor CJ, Falick AM, Lim WA. 2006. The Ste5 scaffold allosterically modulates signaling output of the yeast mating pathway. Science 311: 822-826.

Boden G, Duan X, Homko C, Molina EJ, Song W, Perez O, Cheung P, Merali S. 2008. Increase in endoplasmic reticulum stress-related proteins and genes in adipose tissue of obese, insulin-resistant individuals. Diabetes 57: 2438-2444.

Boden G, Song W, Duan X, Cheung P, Kresge K, Barrero C, Merali S. 2011. Infusion of glucose and lipids at physiological rates causes acute endoplasmic reticulum stress in rat liver. Obesity 19: 1366-1373.

Brancho D, Tanaka N, Jaeschke A, Ventura JJ, Kelkar N, Tanaka Y, Kyuuma M, Takeshita T, Flavell RA, Davis RJ. 2003. Mechanism of p38 MAP kinase activation in vivo. Genes Dev 17: 1969-1978.

Bromati CR, Lellis-Santos C, Yamanaka TS, Nogueira TCA, Leonelli M, Caperuto LC, Gorjao R, Leite AR, Anhe GF, Bordin S. 2011. UPR induces transient burst of apoptosis in islets of early lactating rats through reduced AKT phosphorylation via ATF4/CHOP stimulation of TRB3 expression. Am J Physiol 300: R92-R100.

Calfon M, Zeng H, Urano F, Till JH, Hubbard SR, Harding HP, Clark SG, Ron D. 2002. IRE1 couples endoplasmic reticulum load to secretory capacity by processing the XBP-1 mRNA. Nature 415: 92-96.

Canagarajah BJ, Khokhlatchev A, Cobb MH, Goldsmith EJ. 1997. Activation mechanism of the MAP kinase ERK2 by dual phosphorylation. Cell 90: 859-869.

Cargnello M, Roux PP. 2011. Activation and function of the MAPKs and their substrates, the MAPK-activated protein kinases. Microbiol Mol Biol Rev 75: 50-83.

Caricilli A, Picardi P, de Abreu L, Ueno M, Prada P, Ropelle E, Hirabara S, Vieira P, Camara N, Curi R, et al. 2011. Gut microbiota is a key modulator of insulin resistance in TLR 2 knockout mice. PLoS Biol 9: e1001212.

Carlson SM, Chouinard CR, Labadorf A, Lam CJ, Schmelzle K, Fraenkel E, White FM. 2011. Large-scale discovery of ERK2 substrates identifies ERK-mediated transcriptional regulation by ETV3. Sci Signal 4: rs11.

Caunt CJ, Keyse SM. 2013. Dual-specificity MAP kinase phosphatases (MKPs): Shaping the outcome of MAP kinase signalling. FEBS J 280: 489-504.

Chan J, Cooney G, Biden T, Laybutt D. 2011. Differential regulation of adaptive and apoptotic unfolded protein response signalling by cyto- kine-induced nitric oxide production in mouse pancreatic $\beta$ cells. Diabetologia 54: 1766-1776.

Chang CI, Xu BE, Akella R, Cobb MH, Goldsmith EJ. 2002. Crystal structures of MAP kinase p38 complexed to the docking sites on its nuclear substrate MEF2A and activator MKK3b. Mol Cell 9: 12411249.

Chen ZJ. 2012. Ubiquitination in signaling to and activation of IKK. Immunol Rev 246: 95-106.

Chen X, Shen J, Prywes R. 2002. The luminal domain of ATF6 senses endoplasmic reticulum (ER) stress and causes translocation of ATF6 from the ER to the Golgi. J Biol Chem 277: 13045-13052.

Chi H, Lu B, Takekawa M, Davis RJ, Flavell RA. 2004. GADD45ß/ GADD45 $\gamma$ and MEKK4 comprise a genetic pathway mediating STAT4-independent IFN $\gamma$ production in T cells. EMBO J 23: 15761586.

Clark A, Dean J, Tudor C, Saklatvala J. 2009. Post-transcriptional gene regulation by MAP kinases via AU-rich elements. Front Biosci 14: $847-871$.

Conze D, Krahl T, Kennedy N, Weiss L, Lumsden J, Hess P, Flavell RA, Le Gros G, Davis RJ, Rincon M. 2002. c-Jun $\mathrm{NH}_{2}$-terminal kinase (JNK)1 and JNK2 have distinct roles in $\mathrm{CD}^{+}{ }^{+} \mathrm{T}$ cell activation. J Exp Med 195: $811-823$.

Copps KD, White MF. 2012. Regulation of insulin sensitivity by serine/ threonine phosphorylation of insulin receptor substrate proteins IRS1 and IRS2. Diabetologia 55: 2565-2582.

Cox JS, Walter P. 1996. A novel mechanism for regulating activity of a transcription factor that controls the unfolded protein response. Cell 87: $391-404$

Cox JS, Shamu CE, Walter P. 1993. Transcriptional induction of genes encoding endoplasmic reticulum resident proteins requires a transmembrane protein kinase. Cell 73: 1197-1206.

Coyle SM, Gilbert WV, Doudna JA. 2009. Direct link between RACK1 function and localization at the ribosome in vivo. Mol Cell Biol 29: $1626-1634$.

Cretenet G, Le Clech M, Gachon F. 2010. Circadian clock-coordinated 12 hr period rhythmic activation of the IRE1 $\alpha$ pathway controls lipid metabolism in mouse liver. Cell Metab 11: 47-57.

Cuadrado A, Nebreda AR. 2010. Mechanisms and functions of p38 MAPK signalling. Biochem J 429: 403-417.

Cuenda A, Rousseau S. 2007. p38 MAP-kinases pathway regulation, function and role in human diseases. Biochim Biophys Acta 1773: $1358-1375$

Cullinan SB, Diehl JA. 2006. Coordination of ER and oxidative stress signaling: The PERK/Nrf2 signaling pathway. Int J Biochem Cell Biol 38: $317-332$.

Cullinan SB, Zhang D, Hannink M, Arvisais E, Kaufman RJ, Diehl JA. 2003. Nrf2 is a direct PERK substrate and effector of PERK-dependent cell survival. Mol Cell Biol 23: 7198-7209.

Das M, Sabio G, Jiang F, Rincon M, Flavell RA, Davis RJ. 2009. Induction of hepatitis by JNK-mediated expression of TNF- $\alpha$. Cell 136: 249-260.

Das M, Garlick DS, Greiner DL, Davis RJ. 2011. The role of JNK in the development of hepatocellular carcinoma. Genes Dev 25: 634-645.

Davis RJ. 2000. Signal transduction by the JNK group of MAP kinases. Cell 103: 239-252.

Delepine M, Nicolino M, Barrett T, Golamaully M, Lathrop GM, Julier C. 2000. EIF2AK3, encoding translation initiation factor $2 \alpha$ kinase 3 , is mutated in patients with Wolcott-Rallison syndrome. Nat Genet 25: 406-409.

Deleris P, Trost M, Topisirovic I, Tanguay PL, Borden KL, Thibault P, Meloche S. 2011. Activation loop phosphorylation of ERK3/ERK4 by group I p21-activated kinases (PAKs) defines a novel PAK-ERK3/ 4-MAPK-activated protein kinase 5 signaling pathway. J Biol Chem 286: 6470-6478.

Deng J, Lu PD, Zhang Y, Scheuner D, Kaufman RJ, Sonenberg N, Harding HP, Ron D. 2004. Translational repression mediates activation of nu- 
clear factor $\kappa \mathrm{B}$ by phosphorylated translation initiation factor 2. Mol Cell Biol 24: 10161-10168.

Dong C, Yang DD, Tournier C, Whitmarsh AJ, Xu J, Davis RJ, Flavell RA. 2000. JNK is required for effector T-cell function but not for T-cell activation. Nature 405: 91-94.

Dong C, Davis RJ, Flavell RA. 2002. MAP kinases in the immune response. Annu Rev Immunol 20: 55-72.

Donnelly N, Gorman AM, Gupta S, Samali A. 2013. The eIF2 $\alpha$ kinases: Their structures and functions. Cell Mol Life Sci 70: 1252-1256.

Duesbery NS, Webb CP, Leppla SH, Gordon VM, Klimpel KR, Copeland TD, Ahn NG, Oskarsson MK, Fukasawa K, Paull KD, et al. 1998. Proteolytic inactivation of MAP-kinase-kinase by anthrax lethal factor. Science 280: 734-737.

Eguchi K, Manabe I, Oishi-Tanaka Y, Ohsugi M, Kono N, Ogata F, Yagi N, Ohto U, Kimoto M, Miyake K, et al. 2012. Saturated fatty acid and TLR signaling link $\beta$ cell dysfunction and islet inflammation. Cell Metab 15: $518-533$.

Ellgaard L, Helenius A. 2003. Quality control in the endoplasmic reticulum. Nat Rev Mol Cell Biol 4: 181-191.

English A, Zurek N, Voeltz G. 2009. Peripheral ER structure and function. Curr Opin Cell Biol 21: 596-602.

Enslen H, Davis RJ. 2001. Regulation of MAP kinases by docking domains. Biol Cell 93: 5-14.

Fanger GR, Johnson NL, Johnson GL. 1997. MEK kinases are regulated by EGF and selectively interact with Rac/Cdc42. EMBO J 16: 49614972.

Fleming Y, Armstrong CG, Morrice N, Paterson A, Goedert M, Cohen P. 2000. Synergistic activation of stress-activated protein kinase 1/c-Jun $\mathrm{N}$-terminal kinase (SAPK1/JNK) isoforms by mitogen-activated protein kinase kinase 4 (MKK4) and MKK7. Biochem J 352: 145-154.

Fonseca SG, Fukuma M, Lipson KL, Nguyen LX, Allen JR, Oka Y, Urano F. 2005. WFS1 is a novel component of the unfolded protein response and maintains homeostasis of the endoplasmic reticulum in pancreatic $\beta$-cells. J Biol Chem 280: 39609-39615.

Fonseca SG, Ishigaki S, Oslo CM, Lu S, Lipson KL, Ghosh R, Hayashi E, Ishihara H, Oka Y, Permutt MA, et al. 2010. Wolfram syndrom 1 gene negatively regulate ER stress signaling in rodent and human cells. JClin Invest 120: 744-755.

Friedlander R, Jarosch E, Urban J, Volkwein C, Sommer T. 2000. A regulatory link between ER-associated protein degradation and the unfolded-protein response. Nat Cell Biol 2: 379-384.

Fu S, Watkins SM, Hotamisligil GS. 2012. The role of endoplasmic reticulum in hepatic lipid homeostasis and stress signaling. Cell Metab 15: 623-634.

Gallo KA, Johnson GL. 2002. Mixed-lineage kinase control of JNK and p38 MAPK pathways. Nat Rev Mol Cell Biol 3: 663-672.

Gardner B, Walter P. 2011. Unfolded proteins are Ire1-activating ligands that directly induce the unfolded protein response. Science 333: 18911894.

Garrington TP, Ishizuka T, Papst PJ, Chayama K, Webb S, Yujiri T, Sun W, Sather S, Russell DM, Gibson SB, et al. 2000. MEKK2 gene disruption causes loss of cytokine production in response to IgE and c-Kit ligand stimulation of ES cell-derived mast cells. EMBO J 19: 5387-5395.

Gee H, Noh S, Tang B, Kim K, Lee M. 2011. Rescue of $\Delta$ F508-CFTR trafficking via a GRASP-dependent unconventional secretion pathway. Cell 146: 746-760.

Gething MJ, Sambrook J. 1992. Protein folding in the cell. Nature 355: $33-45$.

Gonzalez-Teran B, Cortes JR, Manieri E, Matesanz N, Verdugo A, Rodriguez ME, Gonzalez-Rodriguez A, Valverde A, Martin P, Davis RJ, et al. 2013. Eukaryotic elongation factor 2 controls TNF- $\alpha$ translation in LPS-induced hepatitis. J Clin Invest 123: 164-178.

Good M, Tang G, Singleton J, Remenyi A, Lim WA. 2009. The Ste5 scaffold directs mating signaling by catalytically unlocking the Fus3 MAP kinase for activation. Cell 136: 1085-1097.

Good MC, Zalatan JG, Lim WA. 2011. Scaffold proteins: Hubs for controlling the flow of cellular information. Science 332: 680-686.
Gotoh T, Mori M. 2006. Nitric oxide and endoplasmic reticulum stress. Arterioscler Thromb Vasc Biol 26: 1439-1446.

* Green DR, Llambi F. 2014. Cell death signaling. Cold Spring Harb Perspect Biol doi: 10.1101/cshperspect.a006080.

Gregor MF, Hotamisligil GS. 2011. Inflammatory mechanisms in obesity. Annu Rev Immunol 29: 415-445.

Gregor MF, Yang L, Fabbrini E, Mohammed BS, Eagon JC, Hotamisligil GS, Klein S. 2009. Endoplasmic reticulum stress is reduced in tissues of obese subjects after weight loss. Diabetes 58: 693-700.

Gupta S, Barrett T, Whitmarsh AJ, Cavanagh J, Sluss HK, Derijard B, Davis RJ. 1996. Selective interaction of JNK protein kinase isoforms with transcription factors. EMBO J 15: 2760-2770.

Han MS, Jung DY, Morel C, Lakhani SA, Kim JK, Flavell RA, Davis RJ. 2013. JNK expression by macrophages promotes obesity-induced insulin resistance and inflammation. Science 339: 218-222.

* Hardie DG. 2012. Organismal carbohydrate and lipid homeostasis. Cold Spring Harb Perspect Biol 4: a006031.

Harding HP, Zhang Y, Ron D. 1999. Protein translation and folding are coupled by an endoplasmic-reticulum-resident kinase. Nature 397: $271-274$

Harding HP, Novoa I, Zhang Y, Zeng H, Wek R, Schapira M, Ron D. 2000. Regulated translation initiation controls stress-induced gene expression in mammalian cells. Mol Cell 6: 1099-1108.

Harding HP, Zeng H, Zhang Y, Jungries R, Chung P, Plesken H, Sabatini DD, Ron D. 2001. Diabetes mellitus and exocrine pancreatic dysfunction in $\mathrm{Perk}^{-/-}$mice reveals a role for translational control in secretory cell survival. Mol Cell 7: 1153-1163.

Harding HP, Zhang Y, Zeng H, Novoa I, Lu PD, Calfon M, Sadri N, Yun C, Popko B, Paules R, et al. 2003. An integrated stress response regulates amino acid metabolism and resistance to oxidative stress. Mol Cell 11: 619-633.

Hasegawa M, Cuenda A, Spillantini MG, Thomas GM, Buée-Scherrer V, Cohen P, Goedert M. 1999. Stress-activated protein kinase-3 interacts with the PDZ domain of $\alpha 1$-syntrophin. A mechanism for specific substrate recognition. J Biol Chem 274: 12626-12631.

Hatori M, Hirota T, Iitsuka M, Kurabayashi N, Haraguchi S, Kokame K, Sato R, Nakai A, Miyata T, Tsutsui K, et al. 2011. Light-dependent and circadian clock-regulated activation of sterol regulatory element-binding protein, X-box-binding protein 1 , and heat shock factor pathways. Proc Natl Acad Sci 108: 4864-4869.

Hayashi T, Rizzuto R, Hajnoczky G, Su TP. 2009. MAM: More than just a housekeeper. Trends Cell Biol 19: 81-88.

Heazlewood CK, Cook MC, Eri R, Price GR, Tauro SB, Taupin D, Thornton DJ, Png CW, Crockford TL, Cornall RJ, et al. 2008. Aberrant mucin assembly in mice causes endoplasmic reticulum stress and spontaneous inflammation resembling ulcerative colitis. PLoS Med 5: e54.

Heo YS, Kim SK, Seo CI, Kim YK, Sung BJ, Lee HS, Lee JI, Park SY, Kim $\mathrm{JH}$, Hwang KY, et al. 2004. Structural basis for the selective inhibition of JNK1 by the scaffolding protein JIP1 and SP600125. EMBO J 23: 2185-2195.

Hinnebusch AG, Lorsch JR. 2012. The mechanism of eukaryotic translation initiation: New insights and challenges. Cold Spring Harb Perspect Biol 4: a011544.

Hirosumi J, Tuncman G, Chang L, Gorgun CZ, Uysal KT, Maeda K, Karin M, Hotamisligil GS. 2002. A central role for JNK in obesity and insulin resistance. Nature 420: 333-336.

Holcik M, Sonenberg N. 2005. Translational control in stress and apoptosis. Nat Rev Mol Cell Biol 6: 318-327.

Hollien J, Weissman JS. 2006. Decay of endoplasmic reticulum-localized mRNAs during the unfolded protein response. Science 313: 104-107.

Holzer RG, Park EJ, Li N, Tran H, Chen M, Choi C, Solinas G, Karin M. 2011. Saturated fatty acids induce c-Src clustering within membrane subdomains, leading to JNK activation. Cell 147: 173-184.

Hotamisligil GS. 2010. Endoplasmic reticulum stress and the inflammatory basis of metabolic disease. Cell 140: 900-917.

Hou SW, Zhi HY, Pohl N, Loesch M, Qi XM, Li RS, Basir Z, Chen G. 2010. PTPH1 dephosphorylates and cooperates with p38 $\gamma$ MAPK to in- 
crease ras oncogenesis through PDZ-mediated interaction. Cancer Res 70: $2901-2910$.

Hu P, Han Z, Couvillon AD, Kaufman RJ, Exton JH. 2006. Autocrine tumor necrosis factor $\alpha$ links endoplasmic reticulum stress to the membrane death receptor pathway through IRE1 $\alpha$-mediated NF- $\kappa B$ activation and down-regulation of TRAF2 expression. Mol Cell Biol 26: $3071-3084$.

Hubner A, Barrett T, Flavell RA, Davis RJ. 2008. Multisite phosphorylation regulates Bim stability and apoptotic activity. Mol Cell 30: 415425.

Hubner A, Cavanagh-Kyros J, Rincon M, Flavell RA, Davis RJ. 2010. Functional cooperation of the proapoptotic Bcl2 family proteins Bmf and Bim in vivo. Mol Cell Biol 30: 98-105.

Ishihara H, Takeda S, Tamura A, Takahashi R, Yamaguchi S, Takei D, Yamada T, Inoue H, Soga H, Katagiri H, et al. 2004. Disruption of the WFS1 gene in mice causes progressive $\beta$-cell loss and impaired stimulus-secretion coupling in insulin secretion. Hum Mol Genet 13: $1159-1170$.

Jacobs D, Glossip D, Xing H, Muslin AJ, Kornfeld K. 1999. Multiple docking sites on substrate proteins form a modular system that mediates recognition by ERK MAP kinase. Genes Dev 13: 163-175.

Jaeschke A, Davis RJ. 2007. Metabolic stress signaling mediated by mixed-lineage kinases. Mol Cell 27: 498-508.

Jaeschke A, Czech MP, Davis RJ. 2004. An essential role of the JIP1 scaffold protein for JNK activation in adipose tissue. Genes Dev 18: 1976-1980.

Jiang HY, Wek SA, McGrath BC, Scheuner D, Kaufman RJ, Cavener DR, Wek RC. 2003. Phosphorylation of the $\alpha$ subunit of eukaryotic initiation factor 2 is required for activation of NF- $\mathrm{B}$ in response to diverse cellular stresses. Mol Cell Biol 23: 5651-5663.

Jiang HY, Wek SA, McGrath BC, Lu D, Hai T, Harding HP, Wang X, Ron D, Cavener DR, Wek RC. 2004. Activating transcription factor 3 is integral to the eukaryotic initiation factor 2 kinase stress response. Mol Cell Biol 24: 1365-1377.

Jiao P, Ma J, Feng B, Zhang H, Diehl JA, Chin YE, Yan W, Xu H. 2011. FFAinduced adipocyte inflammation and insulin resistance: Involvement of ER stress and IKK $\beta$ pathways. Obesity 19: 483-491.

* Julius D, Nathans J. 2012. Signaling by sensory receptors. Cold Spring Harb Perspect Biol 4: a005991.

Kammoun HL, Chabanon H, Hainault I, Luquet S, Magnan C, Koike T, Ferre P, Foufelle F. 2009. GRP78 expression inhibits insulin and ER stress-induced SREBP-1c activation and reduces hepatic steatosis in mice. J Clin Invest 119: 1201-1215.

Kaneko M, Niinuma Y, Nomura Y. 2003. Activation signal of nuclear factor- $\mathrm{KB}$ in response to endoplasmic reticulum stress is transduced via IRE1 and tumor necrosis factor receptor-associated factor 2. Biol Pharm Bull 26: 931-935.

Kant S, Swat W, Zhang S, Zhang ZY, Neel BG, Flavell RA, Davis RJ. 2011. TNF-stimulated MAP kinase activation mediated by a Rho family GTPase signaling pathway. Genes Dev 25: 2069-2078.

Kant S, Barrett T, Vertii A, Noh YH, Jung DY, Kim JK, Davis RJ. 2013. Role of the mixed-lineage protein kinase pathway in the metabolic stress response to obesity. Cell Rep 4: 681-688.

Kars M, Yang L, Gregor MF, Mohammed BS, Pietka TA, Finck BN, Patterson BW, Horton JD, Mittendorfer B, Hotamisligil GS, et al. 2010. Tauroursodeoxycholic Acid may improve liver and muscle but not adipose tissue insulin sensitivity in obese men and women. Diabetes 59: $1899-1905$.

Kesavan K, Lobel-Rice K, Sun W, Lapadat R, Webb S, Johnson GL, Garrington TP. 2004. MEKK2 regulates the coordinate activation of ERK5 and JNK in response to FGF-2 in fibroblasts. J Cell Physiol 199: 140148.

Keyse SM. 2008. Dual-specificity MAP kinase phosphatases (MKPs) and cancer. Cancer Metastasis Rev 27: 253-261.

Kim YK, Kim KS, Lee AS. 1987. Regulation of the glucose-regulated protein genes by $\beta$-mercaptoethanol requires de novo protein syn- thesis and correlates with inhibition of protein glycosylation. J Cell Physiol 133: 553-559.

Klionsky D. 2010. The molecular machinery of autophagy and its role in physiology and disease. Semin Cell Dev Biol 21: 663.

Kokame K, Kato H, Miyata T. 2001. Identification of ERSE-II, a new cisacting element responsible for the ATF6-dependent mammalian unfolded protein response. J Biol Chem 276: 9199-9205.

Kostova Z, Wolf DH. 2003. For whom the bell tolls: Protein quality control of the endoplasmic reticulum and the ubiquitin-proteasome connection. EMBO J 22: 2309-2317.

Kozutsumi Y, Segal M, Normington K, Gething MJ, Sambrook J. 1988. The presence of malfolded proteins in the endoplasmic reticulum signals the induction of glucose-regulated proteins. Nature 332: 462-464.

Kroemer G, Marino G, Levine B. 2010. Autophagy and the integrated stress response. Mol Cell 40: 280-293.

Kuan CY, Whitmarsh AJ, Yang DD, Liao G, Schloemer AJ, Dong C, Bao J, Banasiak KJ, Haddad GG, Flavell RA, et al. 2003. A critical role of neural-specific JNK3 for ischemic apoptosis. Proc Natl Acad Sci 100: 15184-15189.

Ladiges WC, Knoblaugh SE, Morton JF, Korth MJ, Sopher BL, Baskin CR, MacAuley A, Goodman AG, LeBoeuf RC, Katze MG. 2005. Pancreatic $\beta$-cell failure and diabetes in mice with a deletion mutation of the endoplasmic reticulum molecular chaperone gene $\mathrm{P} 58^{\mathrm{IPK}}$. Diabetes 54: $1074-1081$.

Lamb JA, Ventura JJ, Hess P, Flavell RA, Davis RJ. 2003. JunD mediates survival signaling by the JNK signal transduction pathway. Mol Cell 11: 1479-1489.

Lamkanfi M, Dixit VM. 2012. Inflammasomes and their roles in health and disease. Annu Rev Cell Dev Biol 28: 137-161.

* Laplante M, Sabatini DM. 2012. mTOR signaling. Cold Spring Harb Perspect Biol 4: a011593.

Lee AH, Iwakoshi NN, Glimcher LH. 2003. XBP-1 regulates a subset of endoplasmic reticulum resident chaperone genes in the unfolded protein response. Mol Cell Biol 23: 7448-7459.

Lee AH, Heidtman K, Hotamisligil GS, Glimcher LH. 2011a. Dual and opposing roles of the unfolded protein response regulated by IRE1 $\alpha$ and XBP1 in proinsulin processing and insulin secretion. Proc Natl Acad Sci 108: 8885-8890.

Lee J, Sun C, Zhou Y, Lee J, Gokalp D, Herrema H, Park SW, Davis RJ, Ozcan U. 2011b. p38 MAPK-mediated regulation of Xbp1s is crucial for glucose homeostasis. Nat Med 17: 1251-1260.

Le Guezennec X, Bulavin DV. 2010. WIP1 phosphatase at the crossroads of cancer and aging. Trends Biochem Sci 35: 109-114.

Lei K, Davis RJ. 2003. JNK phosphorylation of Bim-related members of the Bcl2 family induces Bax-dependent apoptosis. Proc Natl Acad Sci 100: $2432-2437$

Lerner AG, Upton JP, Praveen PV, Ghosh R, Nakagawa Y, Igbaria A, Shen S, Nguyen V, Backes BJ, Heiman M, et al. 2012. IRE1 $\alpha$ induces thioredoxin-interacting protein to activate the NLRP3 inflammasome and promote programmed cell death under irremediable ER stress. Cell Metab 16: $250-264$.

Levine B, Mizushima N, Virgin H. 2011. Autophagy in immunity and inflammation. Nature 469: 323-335.

Li Y, Schwabe RF, DeVries-Seimon T, Yao PM, Gerbod-Giannone MC, Tall AR, Davis RJ, Flavell R, Brenner DA, Tabas I. 2005. Free cholesterol-loaded macrophages are an abundant source of tumor necrosis factor- $\alpha$ and interleukin-6: Model of NF-кB- and map kinase-dependent inflammation in advanced atherosclerosis. J Biol Chem 280: 21763-21772.

Li G, Mongillo M, Chin KT, Harding H, Ron D, Marks AR, Tabas I. 2009. Role of ERO1- $\alpha$-mediated stimulation of inositol 1,4,5-triphosphate receptor activity in endoplasmic reticulum stress-induced apoptosis. $J$ Cell Biol 186: 783-792.

Li H, Korennykh A, Behrman S, Walter P. 2010. Mammalian endoplasmic reticulum stress sensor IRE1 signals by dynamic clustering. Proc Natl Acad Sci 107: 16113-16118. 
* Lim K-H, Staudt LM. 2013. Toll-like receptor signaling. Cold Spring Harb Perspect Biol 5: a011247.

Lu B, Nakamura T, Inouye K, Li J, Tang Y, Lundback P, Valdes-Ferrer SI, Olofsson PS, Kalb T, Roth J, et al. 2012. Novel role of PKR in inflammasome activation and HMGB1 release. Nature 488: 670-674.

Lynes E, Simmen T. 2011. Urban planning of the endoplasmic reticulum (ER): How diverse mechanisms segregate the many functions of the ER. Biochim Biophys Acta 1813: 1893-1905.

Ma Y, Brewer JW, Diehl JA, Hendershot LM. 2002. Two distinct stress signaling pathways converge upon the $\mathrm{CHOP}$ promoter during the mammalian unfolded protein response. J Mol Biol 318: 1351-1365.

Marciniak SJ, Ron D. 2006. Endoplasmic reticulum stress signaling in disease. Physiol Rev 86: 1133-1149.

Marciniak SJ, Yun CY, Oyadomari S, Novoa I, Zhang Y, Jungreis R, Nagata K, Harding HP, Ron D. 2004. CHOP induces death by promoting protein synthesis and oxidation in the stressed endoplasmic reticulum. Genes Dev 18: 3066-3077.

Martinon F, Chen X, Lee A, Glimcher L. 2010. TLR activation of the transcription factor XBP1 regulates innate immune responses in macrophages. Nat Immunol 11: 411-418.

Matsukawa J, Matsuzawa A, Takeda K, Ichijo H. 2004. The ASK1-MAP kinase cascades in mammalian stress response. J Biochem 136: 261265.

Matsuzawa A, Nishitoh H, Tobiume K, Takeda K, Ichijo H. 2002. Physiological roles of ASK1-mediated signal transduction in oxidative stress- and endoplasmic reticulum stress-induced apoptosis: Advanced findings from ASK1 knockout mice. Antioxid Redox Signal 4: $415-425$.

Mazzitelli S, Xu P, Ferrer I, Davis RJ, Tournier C. 2011. The loss of c-Jun $\mathrm{N}$-terminal protein kinase activity prevents the amyloidogenic cleavage of amyloid precursor protein and the formation of amyloid plaques in vivo. J Neurosci 31: 16969-16976.

McAlees JW, Sanders VM. 2009. Hematopoietic protein tyrosine phosphatase mediates $\beta 2$-adrenergic receptor-induced regulation of p38 mitogen-activated protein kinase in B lymphocytes. Mol Cell Biol 29: 675-686.

McCullough KD, Martindale JL, Klotz LO, Aw TY, Holbrook NJ. 2001. Gadd153 sensitizes cells to endoplasmic reticulum stress by downregulating $\mathrm{Bcl} 2$ and perturbing the cellular redox state. Mol Cell Biol 21: $1249-1259$.

McGuckin MA, Eri RD, Das I, Lourie R, Florin TH. 2011. Intestinal secretory cell ER stress and inflammation. Biochem Soc Trans 39: 1081-1085.

Meusser B, Hirsch C, Jarosch E, Sommer T. 2005. ERAD: The long road to destruction. Nat Cell Biol 7: 766-772.

Mighiu PI, Filippi BM, Lam TK. 2012. Linking inflammation to the brain-liver axis. Diabetes 61: 1350-1352.

Milanski M, Arruda AP, Coope A, Ignacio-Souza LM, Nunez CE, Roman EA, Romanatto T, Pascoal LB, Caricilli AM, Torsoni MA, et al. 2012. Inhibition of hypothalamic inflammation reverses diet-induced insulin resistance in the liver. Diabetes 61: 1455-1462.

Miyake Z, Takekawa M, Ge Q, Saito H. 2007. Activation of MTK1/ MEKK4 by GADD45 through induced N-C dissociation and dimerization-mediated trans autophosphorylation of the MTK1 kinase domain. Mol Cell Biol 27: 2765-2776.

Morel C, Carlson SM, White FM, Davis RJ. 2009. Mcl-1 integrates the opposing actions of signaling pathways that mediate survival and apoptosis. Mol Cell Biol 29: 3845-3852.

Morel C, Standen CL, Jung DY, Gray S, Ong H, Flavell RA, Kim JK, Davis RJ. 2010. Requirement of JIP1-mediated c-Jun N-terminal kinase activation for obesity-induced insulin resistance. Mol Cell Biol 30: 46164625.

Mori K. 2000. Tripartite management of unfolded proteins in the endoplasmic reticulum. Cell 101: 451-454.

Mori K, Ma W, Gething MJ, Sambrook J. 1993. A transmembrane protein with a cdc2 $2^{+} / \mathrm{CDC} 28$-related kinase activity is required for signaling from the ER to the nucleus. Cell 74: 743-756.
* Morrison DK. 2012. MAP kinase pathways. Cold Spring Harb Perspect Biol 4: a011254.

Morrison DK, Davis RJ. 2003. Regulation of MAP kinase signaling modules by scaffold proteins in mammals. Annu Rev Cell Dev Biol 19: 91118.

Nakamura K, Johnson GL. 2007. Noncanonical function of MEKK2 and MEK5 PB1 domains for coordinated extracellular signal-regulated kinase 5 and c-Jun N-terminal kinase signaling. Mol Cell Biol 27: $4566-4577$.

Nakamura T, Furuhashi M, Li P, Cao H, Tuncman G, Sonenberg N, Gorgun CZ, Hotamisligil GS. 2010. Double-stranded RNA-dependent protein kinase links pathogen sensing with stress and metabolic homeostasis. Cell 140: 338-348.

Nakatani Y, Kaneto H, Kawamori D, Yoshiuchi K, Hatazaki M, Matsuoka TA, Ozawa K, Ogawa S, Hori M, Yamasaki Y, et al. 2005. Involvement of endoplasmic reticulum stress in insulin resistance and diabetes. J Biol Chem 280: 847-851.

* Newton K, Dixit VM. 2012. Signaling in innate immunity and inflammation. Cold Spring Harb Perspect Biol 4: a006049.

Niehrs C, Schäfer A. 2012. Active DNA demethylation by Gadd45 and DNA repair. Trends Cell Biol 22: 220-227.

Nikawa J, Yamashita S. 1992. IRE1 encodes a putative protein kinase containing a membrane-spanning domain and is required for inositol phototrophy in Saccharomyces cerevisiae. Mol Microbiol 6: 1441-1446.

Nikawa J, Akiyoshi M, Hirata S, Fukuda T. 1996. Saccharomyces cerevisiae IRE2/HAC1 is involved in IRE1-mediated KAR2 expression. Nucleic Acids Res 24: 4222-4226.

Noubade R, Krementsov DN, Del Rio R, Thornton T, Nagaleekar V, Saligrama N, Spitzack A, Spach K, Sabio G, Davis RJ, et al. 2011. Activation of $\mathrm{p} 38$ MAPK in CD4 T cells controls IL-17 production and autoimmune encephalomyelitis. Blood 118: 3290-3300.

Novoa I, Zeng H, Harding HP, Ron D. 2001 Feedback inhibition of the unfolded protein response by GADD34-mediated dephosphorylation of eIF2 $\alpha$. J Cell Biol 153: 1011-1022.

Nozaki J, Kubota H, Yoshida H, Naitoh M, Goji J, Yoshinaga T, Mori K, Koizumi A, Nagata K. 2004. The endoplasmic reticulum stress response is stimulated through the continuous activation of transcription factors ATF6 and XBP1 in Ins2 $2^{+/ A k i t a}$ pancreatic $\beta$ cells. Genes Cells 9: 261-270.

Ogata M, Hino S, Saito A, Morikawa K, Kondo S, Kanemoto S, Murakami T, Taniguchi M, Tanii I, Yoshinaga K, et al. 2006. Autophagy is activated for cell survival after endoplasmic reticulum stress. Mol Cell Biol 26: 9220-9231.

Oslowski CM, Hara T, O’Sullivan-Murphy B, Kanekura K, Lu S, Hara M, Ishigaki S, Zhu LJ, Hayashi E, Hui ST, et al. 2012. Thioredoxin-interacting protein mediates ER stress-induced $\beta$ cell death through initiation of the inflammasome. Cell Metab 16: 265-273.

Owens DM, Keyse SM. 2007. Differential regulation of MAP kinase signalling by dual-specificity protein phosphatases. Oncogene 26: $3203-$ 3213.

Ozawa K, Miyazaki M, Matsuhisa M, Takano K, Nakatani Y, Hatazaki M, Tamatani T, Yamagata K, Miyagawa J, Kitao Y, et al. 2005. The endoplasmic reticulum chaperone improves insulin resistance in type 2 diabetes. Diabetes 54: 657-663.

Ozcan L, Tabas I. 2012. Role of endoplasmic reticulum stress in metabolic disease and other disorders. Annu Rev Med 63: 317-328.

Ozcan U, Cao Q, Yilmaz E, Lee AH, Iwakoshi NN, Ozdelen E, Tuncman G, Gorgun C, Glimcher LH, Hotamisligil GS. 2004. Endoplasmic reticulum stress links obesity, insulin action, and type 2 diabetes. Science 306: 457-461.

Ozcan U, Yilmaz E, Ozcan L, Furuhashi M, Vaillancourt E, Smith RO, Gorgun CZ, Hotamisligil GS. 2006. Chemical chaperones reduce ER stress and restore glucose homeostasis in a mouse model of type 2 diabetes. Science 313: 1137-1140.

Ozcan U, Ozcan L, Yilmaz E, Duvel K, Sahin M, Manning BD, Hotamisligil GS. 2008. Loss of the tuberous sclerosis complex tumor sup- 
pressors triggers the unfolded protein response to regulate insulin signaling and apoptosis. Mol Cell 29: 541-551.

Ozcan L, Wong CC, Li G, Xu T, Pajvani U, Park SK, Wronska A, Chen BX, Marks AR, Fukamizu A, et al. 2012. Calcium signaling through CaMKII regulates hepatic glucose production in fasting and obesity. Cell Metab 15: 739-751.

Palade GE, Porter KR. 1954. Studies on the endoplasmic reticulum: I. Its identification in cells in situ. J Exp Med 100: 641-656.

Patil C, Walter P. 2001. Intracellular signaling from the endoplasmic reticulum to the nucleus: The unfolded protein response in yeast and mammals. Curr Opin Cell Biol 13: 349-355.

Payne DM, Rossomando AJ, Martino P, Erickson AK, Her JH, Shabanowitz J, Hunt DF, Weber MJ, Sturgill TW. 1991. Identification of the regulatory phosphorylation sites in $\mathrm{pp} 42 /$ mitogen-activated protein kinase (MAP kinase). EMBO J 10: 885-892.

Perier C, Bove J, Wu DC, Dehay B, Choi DK, Jackson-Lewis V, RathkeHartlieb S, Bouillet P, Strasser A, Schulz JB, et al. 2007. Two molecular pathways initiate mitochondria-dependent dopaminergic neurodegeneration in experimental Parkinson's disease. Proc Natl Acad Sci 104: $8161-8166$

Pfaffenbach KT, Nivala AM, Reese L, Ellis F, Wang D, Wei Y, Pagliassotti MJ. 2010. Rapamycin inhibits postprandial-mediated X-box-binding protein-1 splicing in rat liver. J Nutr 140: 879-884.

Pincus D, Chevalier M, Aragón T, Van Anken E, Vidal S, El-Samad H, Walter P. 2010. BiP binding to the ER-stress sensor Irel tunes the homeostatic behavior of the unfolded protein response. PLoS Biol 8: e1000415.

Proud CG. 2009. mTORC1 signalling and mRNA translation. Biochem Soc Trans 37: 227-231.

Purkayastha S, Zhang H, Zhang G, Ahmed Z, Wang Y, Cai D. 2011. Neural dysregulation of peripheral insulin action and blood pressure by brain endoplasmic reticulum stress. Proc Natl Acad Sci 108: 29392944.

Puthalakath H, Strasser A. 2002. Keeping killers on a tight leash: Transcriptional and post-translational control of the pro-apoptotic activity of BH3-only proteins. Cell Death Differ 9: 505-512.

Qiu Y, Mao T, Zhang Y, Shao M, You J, Ding Q, Chen Y, Wu D, Xie D, Lin $X$, et al. 2010. A crucial role for RACK1 in the regulation of glucosestimulated IRE1 $\alpha$ activation in pancreatic $\beta$ cells. Sci Signal 3: ra7.

Raman M, Earnest S, Zhang K, Zhao Y, Cobb MH. 2007. TAO kinases mediate activation of $\mathrm{p} 38$ in response to DNA damage. EMBO J 26: 2005-2014.

Rao RV, Ellerby HM, Bredesen DE. 2004. Coupling endoplasmic reticulum stress to the cell death program. Cell Death Differ 11: 372-380.

Resendez E Jr, Attenello JW, Grafsky A, Chang CS, Lee AS. 1985. Calcium ionophore A23187 induces expression of glucose-regulated genes and their heterologous fusion genes. Mol Cell Biol 5: 1212-1219.

* Rhind N, Russell P. 2012. Signaling pathways that regulate cell division. Cold Spring Harb Perspect Biol 4: a005942.

Robinson MJ, Cobb MH. 1997. Mitogen-activated protein kinase pathways. Curr Opin Cell Biol 9: 180-186.

Rodriguez Limardo RG, Ferreiro DN, Roitberg AE, Marti MA, Turjanski AG. 2011. p38 $\gamma$ activation triggers dynamical changes in allosteric docking sites. Biochemistry 50: 1384-1395.

Ron D, Walter P. 2007. Signal integration in the endoplasmic reticulum unfolded protein response. Nat Rev Mol Cell Biol 8: 519-529.

Rutkowski DT, Kaufman RJ. 2004. A trip to the ER: Coping with stress. Trends Cell Biol 14: 20-28.

Sabio G, Davis RJ. 2010. cJun $\mathrm{NH}_{2}$-terminal kinase 1 (JNK1): Roles in metabolic regulation of insulin resistance. Trends Biochem Sci 35: 490496.

Salvador JM, Mittelstadt PR, Guszczynski T, Copeland TD, Yamaguchi H, Appella E, Fornace AJ Jr, Ashwell JD. 2005. Alternative p38 activation pathway mediated by $\mathrm{T}$ cell receptor-proximal tyrosine kinases. Nat Immunol 6: 390-395.

* Sassone-Corsi P. 2012. The cyclic AMP pathway. Cold Spring Harb Perspect Biol 4: a011148.
Scull CM, Tabas I. 2011. Mechanisms of ER stress-induced apoptosis in atherosclerosis. Arterioscler Thromb Vasc Biol 31: 2792-2797.

Seo HY, Kim YD, Lee KM, Min AK, Kim MK, Kim HS, Won KC, Park JY, Lee KU, Choi HS, et al. 2008. Endoplasmic reticulum stress-induced activation of activating transcription factor 6 decreases insulin gene expression via up-regulation of orphan nuclear receptor small heterodimer partner. Endocrinology 149: 3832-3841.

Sevier C, Kaiser C. 2008. Ero1 and redox homeostasis in the endoplasmic reticulum. Biochim Biophys Acta 1783: 549-556.

Sevier C, Cuozzo J, Vala A, Aslund F, Kaiser C. 2001. A flavoprotein oxidase defines a new endoplasmic reticulum pathway for biosynthetic disulphide bond formation. Nat Cell Biol 3: 874-882.

Shamu CE, Walter P. 1996. Oligomerization and phosphorylation of the Irelp kinase during intracellular signaling from the endoplasmic reticulum to the nucleus. EMBO J 15: 3028-3039.

Sharma NK, Das SK, Mondal AK, Hackney OG, Chu WS, Kern PA, Rasouli N, Spencer HJ, Yao-Borengasser A, Elbein SC. 2008. Endoplasmic reticulum stress markers are associated with obesity in nondiabetic subjects. J Clin Endocrinol Metab 93: 4532-4541.

Sharma G, Pallesen J, Das S, Grassucci R, Langlois R, Hampton CM, Kelly DF, des Georges A, Frank J. 2013. Affinity grid-based cryo-EM of PKC binding to RACK1 on the ribosome. J Struct Biol 181: 190-194.

Shen X, Ellis RE, Lee K, Liu CY, Yang K, Solomon A, Yoshida H, Morimoto R, Kurnit DM, Mori K, et al. 2001. Complementary signaling pathways regulate the unfolded protein response and are required for C. elegans development. Cell 107: 893-903.

Shen J, Chen X, Hendershot L, Prywes R. 2002. ER stress regulation of ATF6 localization by dissociation of BiP/GRP78 binding and unmasking of Golgi localization signals. Dev Cell 3: 99-111.

Shi Y, Vattem KM, Sood R, An J, Liang J, Stramm L, Wek RC. 1998. Identification and characterization of pancreatic eukaryotic initiation factor $2 \alpha$-subunit kinase, PEK, involved in translational control. Mol Cell Biol 18: 7499-7509.

Shimazawa M, Ito Y, Inokuchi Y, Hara H. 2007. Involvement of doublestranded RNA-dependent protein kinase in ER stress-induced retinal neuron damage. Invest Ophthalmol Vis Sci 48: 3729-3736.

Shiu RP, Pouyssegur J, Pastan I. 1977. Glucose depletion accounts for the induction of two transformation-sensitive membrane proteins in Rous sarcoma virus-transformed chick embryo fibroblasts. Proc Natl Acad Sci 74: 3840-3844.

Sidrauski C, Walter P. 1997. The transmembrane kinase Irelp is a sitespecific endonuclease that initiates mRNA splicing in the unfolded protein response. Cell 90: 1031-1039.

Somers J, Pöyry T, Willis AE. 2013. A perspective on mammalian upstream open reading frame function. Int J Biochem Cell Biol 45: 16901700.

Sumara G, Formentini I, Collins S, Sumara I, Windak R, Bodenmiller B, Ramracheya R, Caille D, Jiang H, Platt KA, et al. 2009. Regulation of PKD by the MAPK p38ס in insulin secretion and glucose homeostasis. Cell 136: 235-248.

Szegezdi E, Logue SE, Gorman AM, Samali A. 2006. Mediators of endoplasmic reticulum stress-induced apoptosis. EMBO Rep 7: 880-885.

Takekawa M, Saito H. 1998. A family of stress-inducible GADD45-like proteins mediate activation of the stress-responsive MTK1/MEKK4 MAPKKK. Cell 95: 521-530.

Talukdar S, Olefsky JM, Osborn O. 2011. Targeting GPR120 and other fatty acid-sensing GPCRs ameliorates insulin resistance and inflammatory diseases. Trends Pharm Sci 32: 543-550.

Tanoue T, Nishida E. 2003. Molecular recognitions in the MAP kinase cascades. Cell Signal 15: 455-462.

Tournier C, Hess P, Yang DD, Xu J, Turner TK, Nimnual A, Bar-Sagi D, Jones SN, Flavell RA, Davis RJ. 2000. Requirement of JNK for stressinduced activation of the cytochrome $c$-mediated death pathway. Science 288: 870-874.

Tournier C, Dong C, Turner TK, Jones SN, Flavell RA, Davis RJ. 2001. MKK7 is an essential component of the JNK signal transduction path- 
way activated by proinflammatory cytokines. Genes Dev 15: 14191426.

Trusina A, Papa FR, Tang C. 2008. Rationalizing translation attenuation in the network architecture of the unfolded protein response. Proc Natl Acad Sci 105: 20280-20285.

Tu BP, Weissman JS. 2002. The FAD- and $\mathrm{O}_{2}$-dependent reaction cycle of Ero1-mediated oxidative protein folding in the endoplasmic reticulum. Mol Cell 10: 983-994.

Uehara T, Nakamura T, Yao D, Shi ZQ, Gu Z, Ma Y, Masliah E, Nomura Y, Lipton SA. 2006. S-nitrosylated protein-disulphide isomerase links protein misfolding to neurodegeneration. Nature 441: 513-517.

Urano F, Wang X, Bertolotti A, Zhang Y, Chung P, Harding HP, Ron D. 2000. Coupling of stress in the ER to activation of JNK protein kinases by transmembrane protein kinase IRE1. Science 287: 664-666.

Ventura JJ, Cogswell P, Flavell RA, Baldwin AS Jr, Davis RJ. 2004. JNK potentiates TNF-stimulated necrosis by increasing the production of cytotoxic reactive oxygen species. Genes Dev 18: 2905-2915.

Ventura JJ, Hubner A, Zhang C, Flavell RA, Shokat KM, Davis RJ. 2006. Chemical genetic analysis of the time course of signal transduction by JNK. Mol Cell 21: 701-710.

Walter P, Ron D. 2011. The unfolded protein response: From stress pathway to homeostatic regulation. Science 334: 1081-1086.

Wang XZ, Harding HP, Zhang Y, Jolicoeur EM, Kuroda M, Ron D. 1998. Cloning of mammalian Ire1 reveals diversity in the ER stress responses. EMBO J 17: 5708-5717.

* Ward PS, Thompson CB. 2012. Signaling in control of cell growth and metabolism. Cold Spring Harb Perspect Biol 4: a006783.

Wei Y, Pattingre S, Sinha S, Bassik M, Levine B. 2008. JNK1-mediated phosphorylation of $\mathrm{Bcl}-2$ regulates starvation-induced autophagy. Mol Cell 30: 678-688.

Welch WJ, Garrels JI, Thomas GP, Lin JJ, Feramisco JR. 1983. Biochemical characterization of the mammalian stress proteins and identification of two stress proteins as glucose- and $\mathrm{Ca}^{2+}$-ionophore-regulated proteins. J Biol Chem 258: 7102-7111.

Whinston E, Omerza G, Singh A, Tio CW, Winter E. 2013. Activation of the Smk1 mitogen-activated protein kinase by developmentally regulated autophosphorylation. Mol Cell Biol 33: 688-700.

Whitmarsh AJ, Davis RJ. 2000. Regulation of transcription factor function by phosphorylation. Cell Mol Life Sci 57: 1172-1183.

Whitmarsh AJ, Kuan CY, Kennedy NJ, Kelkar N, Haydar TF, Mordes JP, Appel M, Rossini AA, Jones SN, Flavell RA, et al. 2001. Requirement of the JIP1 scaffold protein for stress-induced JNK activation. Genes Dev 15: $2421-2432$.

Wiggins CM, Tsvetkov P, Johnson M, Joyce CL, Lamb CA, Bryant NJ, Komander D, Shaul Y, Cook SJ. 2011. BIM $\mathrm{EL}_{\mathrm{EL}}$, an intrinsically disordered protein, is degraded by $20 \mathrm{~S}$ proteasomes in the absence of polyubiquitylation. J Cell Sci 124: 969-977.

Witzel F, Maddison L, Blüthgen N. 2012. How scaffolds shape MAPK signaling: What we know and opportunities for systems approaches. Front Physiol 3: 475.

Wong HK, Fricker M, Wyttenbach A, Villunger A, Michalak EM, Strasser A, Tolkovsky AM. 2005. Mutually exclusive subsets of BH3-only proteins are activated by the p53 and c-Jun N-terminal kinase/c-Jun signaling pathways during cortical neuron apoptosis induced by arsenite. Mol Cell Biol 25: 8732-8747.

Wu N, Zheng B, Shaywitz A, Dagon Y, Tower C, Bellinger G, Shen CH, Wen J, Asara J, McGraw TE, et al. 2013 AMPK-dependent degradation of TXNIP upon energy stress leads to enhanced glucose uptake via GLUT1. Mol Cell 49: 1167-1175.

Xia Z, Dickens M, Raingeaud J, Davis RJ, Greenberg ME. 1995. Opposing effects of ERK and JNK-p38 MAP kinases on apoptosis. Science 270: $1326-1331$.

Xiao C, Giacca A, Lewis GF. 2011. Sodium phenylbutyrate, a drug with known capacity to reduce endoplasmic reticulum stress, partially alleviates lipid-induced insulin resistance and $\beta$-cell dysfunction in humans. Diabetes 60: 918-924.

Yamada T, Ishihara H, Tamura A, Takahashi R, Yamaguchi S, Takei D, Tokita A, Satake C, Tashiro F, Katagiri H, et al. 2006. WFS1-deficiency increases endoplasmic reticulum stress, impairs cell cycle progression and triggers the apoptotic pathway specifically in pancreatic $\beta$-cells. Hum Mol Genet 15: 1600-1609.

Yamazaki H, Hiramatsu N, Hayakawa K, Tagawa Y, Okamura M, Ogata R, Huang T, Yao J, Paton A, Paton J, et al. 2009. Activation of the Akt-NF$\kappa \mathrm{B}$ pathway by subtilase cytotoxin through the ATF6 branch of the unfolded protein response. J Immunol 183: 1480-1487.

Yang DD, Kuan CY, Whitmarsh AJ, Rincon M, Zheng TS, Davis RJ, Rakic P, Flavell RA. 1997. Absence of excitotoxicity-induced apoptosis in the hippocampus of mice lacking the Jnk3 gene. Nature 389: 865870.

Yecies JL, Manning BD. 2011. mTOR links oncogenic signaling to tumor cell metabolism. J Mol Med 89: 221-228.

Yoneda T, Imaizumi K, Oono K, Yui D, Gomi F, Katayama T, Tohyama M. 2001. Activation of caspase-12, an endoplastic reticulum (ER) resident caspase, through tumor necrosis factor receptor-associated factor 2dependent mechanism in response to the ER stress. J Biol Chem 276: $13935-13940$.

Yoshida H, Haze K, Yanagi H, Yura T, Mori K. 1998. Identification of the cis-acting endoplasmic reticulum stress response element responsible for transcriptional induction of mammalian glucose-regulated proteins. Involvement of basic leucine zipper transcription factors. J Biol Chem 273: 33741-33749.

Yoshida H, Matsui T, Yamamoto A, Okada T, Mori K. 2001. XBP1 mRNA is induced by ATF6 and spliced by IRE1 in response to ER stress to produce a highly active transcription factor. Cell 107: 881-891.

Yoshida H, Matsui T, Hosokawa N, Kaufman RJ, Nagata K, Mori K. 2003. A time-dependent phase shift in the mammalian unfolded protein response. Dev Cell 4: 265-271.

Zhang P, McGrath B, Li S, Frank A, Zambito F, Reinert J, Gannon M, Ma K, McNaughton K, Cavener DR. 2002. The PERK eukaryotic initiation factor $2 \alpha$ kinase is required for the development of the skeletal system, postnatal growth, and the function and viability of the pancreas. Mol Cell Biol 22: 3864-3874.

Zhang X, Zhang G, Zhang H, Karin M, Bai H, Cai D. 2008. Hypothalamic IKK $\beta / N F-\kappa B$ and ER stress link overnutrition to energy imbalance and obesity. Cell 135: 61-73.

Zhao L, Ackerman SL. 2006. Endoplasmic reticulum stress in health and disease. Curr Opin Cell Biol 18: 444-452. 